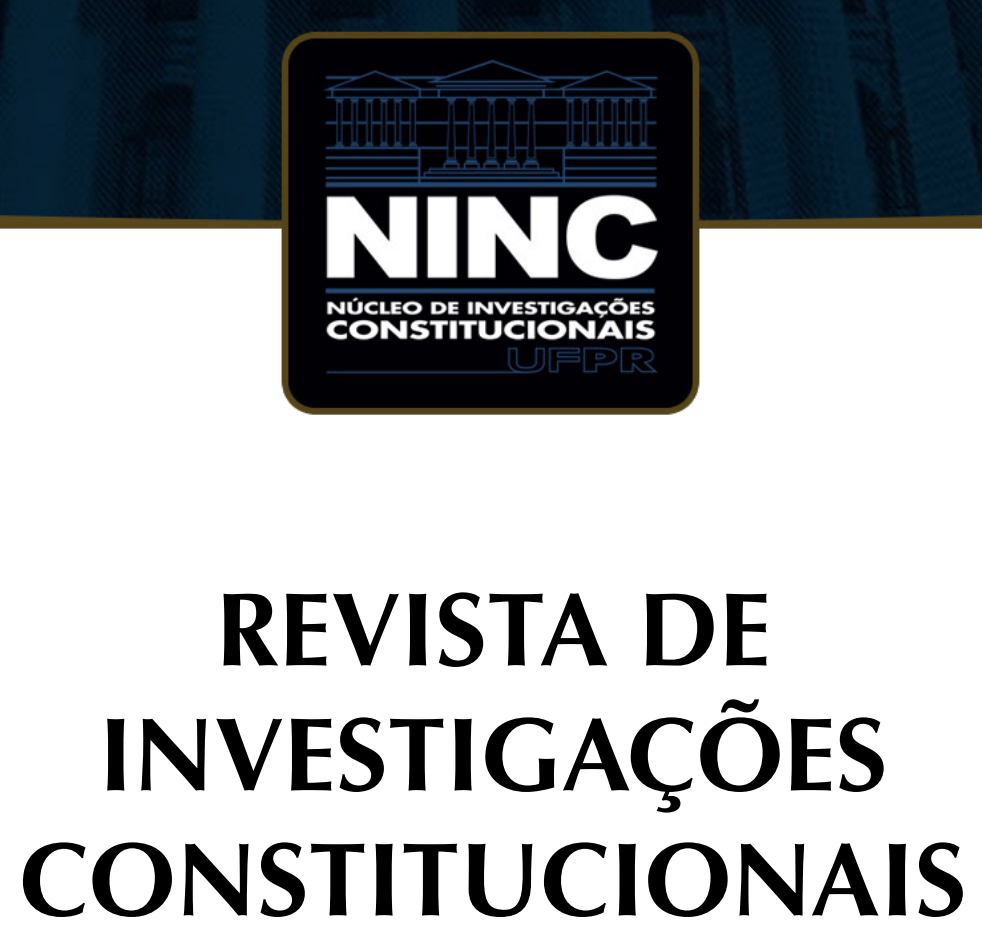

vol. 4 | n. 1 | janeiro/abril 2017 | ISSN 2359-5639 | Periodicidade quadrimestral Curitiba | Núcleo de Investigações Constitucionais da UFPR | www.ninc.com.br 


\title{
Novo Regime Fiscal, autonomia financeira e separação de poderes: uma leitura em favor de sua constitucionalidade
}

\author{
New Fiscal Regime, financial autonomy and separation \\ of powers: a reading in favor of its constitutionality
}

\author{
VANICE REGINA LÍRIO DO VALLE* \\ Universidade Estácio de Sá - UNESA (Brasil) \\ vanicevalle@gmail.com \\ Recebido/Received: 26.01.2017 / January 26th, 2017 \\ Aprovado/Approved: 08.02.2017 / February 8th, 2017
}

Resumo

A introdução de um limite de gastos às estruturas política no nível federal trazida pelo Novo Regime Fiscal já foi objeto de controle judicial em abstrato, baseado na alegada violação do princípio de separação de poderes. A discussão também envolve a preservação da autonomia financeira assegurada pela Constituição ao Judiciário e outras instituições integrantes do sistema de controle. A casuística do Supremo Tribunal Federal acerca do sentido da autonomia financeira examinada neste artigo provê critérios para a análise de constitucionalidade requerida. O artigo também examina a alegação de violação à separação de poderes, considerando seu papel instrumental na preservação de valores constitucionais como democracia, eficiência institucional e direitos fundamentais. A conclusão é de que não há elemento substantivos suficientes a permitir, baseado numa cláusula indeterminada como o é a de separação de poderes, uma proclamação

\section{Abstract:}

The introduction of an expenditure limitation to all political structures in the federal level of government brought by the New Fiscal Regime is already submit to judicial abstract control based on an alleged violation of the separation of powers clause. The discussion also involve the preservation of financial autonomy granted by constitution to the Judiciary and other institutions in the control system. The case law in the Constitutional Court about the meaning of the financial autonomy examined in that article provides some guidance to the analysis of the unconstitutionality allegation. The article also examines the alleged violation of the separation of power clause, considering its instrumental role when it comes to preserving constitutional values as democracy, efficiency and human rights. The conclusion is that there are not substantive elements to allow, based in such a vague clause as separation of powers, an a priori ruling of unconstitutionality.Time alone, can present in the

Como citar esse artigo/How to cite this article: VALLE, Vanice Regina Lírio do. Novo Regime Fiscal, autonomia financeira e separação de poderes: uma leitura em favor de sua constitucionalidade. Revista de Investigações Constitucionais, Curitiba, vol. 4, n. 1, p. 227-258, jan./abr. 2017. DOI:10.5380/rinc.v4i1.50340.

* Professora Permanente do PPGD da Universidade Estácio de Sá - UNESA (Rio de Janeiro-RJ, Brasil). Doutorado em Direito pela Universidade Gama Filho (Rio de Janeiro, Brasil). Visiting Fellow junto ao Human Rights Program da Harvard Law School (USA). Pós-doutorado em Administração pela EBAPE - Escola Brasileira de Administração Pública e de Empresas (FGV/Rio). Membro do Instituto Brasileiro de Direito Processual e Procuradora do Município do Rio de Janeiro. E-mail: vanicevalle@gmail.com. 
apriorística da inconstitucionalidade do Novo Regime Fiscal. Só o tempo poderá apresentar, no plano da aplicação, elementos substantivos que possa corroborar a imputação de inconstitucionalidade.

Palavras-chave: Novo Regime Fiscal; Emenda Constitucional 95; equilíbrio fiscal; autonomia financeira; separação de poderes. application level, substantive elements that might corroborate the alleged unconstitutionality.

Keywords: New Fiscal Regime; Constitutional Amendment 95; fiscal balance; financial autonomy; separation of powers.

\section{SUMÁRIO}

1. Introdução; 2. A Emenda 95 no movimento contínuo de disciplina da matéria financeira pela via do poder constituinte reformador; 3. Desenho geral de conteúdo da Emenda 95; 3.1. A fixação do limite de gastos; 3.2. A atualização do limite de gastos; 3.3. Mecanismos de transparência associados ao Novo Regime Fiscal; 3.4. Efeitos jurídicos da violação dos limites fixados; 4. Autonomia financeira e prerrogativas dela decorrentes na jurisprudência do STF; $\mathbf{5}$. Autonomia orçamentária e separação de poderes: os temas primários de debate; 5.1. Novo Regime Fiscal e alegada violação à autonomia orçamentária; 5.2. Novo Regime Fiscal e alegada violação ao equilíbrio e harmonia entre os poderes; 5.2.1. Novo Regime Fiscal e harmonia com o princípio democrático; 5.2.2. Novo Regime Fiscal, equilíbrio e harmonia entre poderes e especialização funcional; 5.2.3. Novo Regime Fiscal, equilíbrio e harmonia entre poderes proteção a direitos fundamentais; 6 . Conclusão; 7. Referências.

\section{INTRODUÇÃO}

O Novo Regime Fiscal, instituído pela Emenda 95 de 15 de dezembro de 2016 se apresenta como fato novo no quadro normativo nacional que já nasce imerso em polêmica. $O$ intenso debate acerca da conveniência e oportunidade da proposição, seus efeitos na curva de efetividade dos direitos sociais e ainda na integridade e funcionamento do sistema de controle determinou a judicialização preventiva da proposição, com a impetração por Deputados do PT e do PC do B do Mandado de Segurança nº 34.4481, que pretendia o trancamento do processamento legislativo da referida iniciativa. Promulgada a Emenda, já se tem o ajuizamento de ADIN $5633^{2}$ ofertada pela AJUFE, $A M B$ e ANAMATRA, onde se sustenta sob vários ângulos, o vício de raiz da proposição com ênfase nos preceitos que estariam, a ver dos autores, a minar a autonomia financeira do Poder Judiciário e/ou o equilíbrio e harmonia entre os poderes.

Não se pretende, nos limites de um artigo científico, enfrentar um quadro tão amplo de debates sensíveis e de alta complexidade. De outro lado, a Emenda 95 vige, e reclamará dos gestores públicos um esforço de compreensão - ao menos até que se

\footnotetext{
1 BRASIL. Supremo Tribunal Federal. MS 34448 MC, Relator(a): Min. ROBERTO BARROSO, julgado em 10/10/2016, publicado em PROCESSO ELETRÔNICO DJe-218 DIVULG 11/10/2016 PUBLIC 13/10/2016.

2 A ação de controle abstrato, distribuída à Ministra Rosa Weber, teve seu processamento remetido ao rito do art. 12 da Lei 9868/99, com a remessa da apreciação da liminar requerida ao Plenário do Supremo Tribunal Federal.
} 
tenha nova intervenção esclarecedora originária do Parlamento ou mesmo do Supremo Tribunal Federal. Nestes termos, elege-se como objeto do presente artigo a análise dessas duas principais alegações de vício de raiz - violação à autonomia financeira e ao equilíbrio entre poderes - eis que o reconhecimento de qualquer dos dois fundamentos importaria em lançar por terra se não a íntegra, ao menos a essência da proposição convertida em Emenda 95.

Distingue-se igualmente, para os fins dessa análise, os preceitos que constituem a estrutura principal do Novo Regime Fiscal, e aqueles que regulam a transição para este modelo ${ }^{3}$ ou a sua modificação futura. ${ }^{4}$ Os argumentos aqui expendidos se reportam a este corpo principal, reservando-se a análise dos demais preceitos para outra ocasião.

O texto se desenvolverá da seguinte maneira. Na Parte 1 formulam-se as considerações introdutórias e metodológicas. Na Parte 2 explora-se o percurso de tratamento da temática das finanças públicas por intermédio do poder constituinte reformador, evidenciando o espraiamento da matéria para o ADCT, numa curiosa tredestinação dessa espécie normativa. A Parte 3 empreende a um breve percurso da estrutura proposta pela Emenda 95 ao chamado Novo Regime Fiscal, de modo a que se possa compreender o sistema pretendido instituir, premissa à formulação de qualquer juízo crítico na matéria. A Parte 4 percorre a jurisprudência constitucional no tema da autonomia financeira das estruturas institucionais a quem a constituição conferiu esse atributo. A lógica é de que a interpretação constitucional se beneficie de um saber construído por agregação, sendo imprescindível conhecer as premissas já firmadas pela Corte para prosseguir no enfrentamento da questão judicializada. Finalmente, a Parte 5 analisa os dois eixos argumentativos da violação à autonomia financeira e ao equilíbrio e harmonia entre poderes, tendo em conta os preceitos identificados como corpo principal do Novo Regime Fiscal, que instituem a mecânica do limite de gastos em si.

Não se formula aqui qualquer consideração sobre a oportunidade da iniciativa, ou o seu potencial eventualmente regressivo em relação a direitos sociais. A crítica à oportunidade é do campo da política; e a regressividade na seara dos direitos humanos é um exercício de prognóstico que só o tempo poderá confirmar. O que se busca é apresentar os pontos da Emenda 95 que estarão a reclamar um esforço interpretativo mais expressivo, construindo com isso uma pauta reflexiva. O objetivo desse mapeamento de pontos de tensão exegética propostos pela Emenda 95 é permitir uma desejável

3 As normas aqui indicadas como de transição para o Novo Regime Fiscal situam-se no art. $107, \S 7^{\circ}$ e $8^{\circ}$ do ADCT.

4 Esta matéria se tem especificamente regrada no art. 108 ADCT. 
integração sistêmica, não só interna (nos limites da Emenda) como também com o restante do Texto de Base no que toca em especial às finanças públicas. 5

O debate binário, na lógica do "tudo ou nada" que propõe a pura e simples proclamação da inconstitucionalidade da Emenda 95 simplifica um quadro fático cuja complexidade se evidencia pelos inegáveis dados da crise econômica. O papel do intérprete não é se render à simplificação, mas explorar as sutilezas do entorno fático e da argumentação posta, de molde a contribuir para a qualificação do quadro normativo. Essa é a intenção deste artigo.

\section{A EMENDA 95 NO MOVIMENTO CONTÍNUO DE DISCIPLINA DA MATÉRIA FINANCEIRA PELA VIA DO PODER CONSTITUINTE REFORMADOR}

Objetiva a Emenda 95 - é o que se depreende de sua ementa - a fundação de um Novo Regime Fiscal, pautado principalmente na instituição de severas cláusulas de limites pré-estabelecidos de gastos públicos. A referida disciplina vem à luz sob o signo da temporariedade, eis que sujeita ao limite de 20 (vinte) anos, admitida ainda a alteração de alguns de seus componentes já a partir do décimo ano de vigência. ${ }^{6}$ Reforça igualmente a perspectiva efêmera da proposição, a circunstância de que não se tem introduzido no corpo permanente da Constituição qualquer nova disciplina atinente aos particulares aspectos do desenvolvimento da atividade financeira do Estado lato sensu que se veem considerados na Emenda 95, a saber, despesa pública e responsabilidade fiscal.7 A proposta, portanto, em que pese o caráter enganoso da denominação, não é exatamente de um novo regime constitucional na matéria ${ }^{8}$ (expressão que sugere uma inovação que se pretende prossiga vigendo ao longo do tempo), mas de uma disciplina temporária, vocacionada a enfrentar um momento de crise fiscal ${ }^{9}$ cujos traços mais

5 A importância do resgate da ideia da Constituição como sistema já foi abordada em texto anterior: VALLE, V. R. L. A Constituição como sistema: retomando uma premissa à efetividade. In: FERRARI, S.; MENDONÇA, J.S. (Org.). Direito em Público. Homenagem ao Professor Paulo Braga Galvão. Rio de Janeiro: Lumen Juris, 2016. p. 29-49.

6 A abertura à alteração da sistemática instituída pela Emenda 95 se tem no art. 108, acrescido ao ADCT, que autoriza o Presidente da República a propor projeto de lei complementar que altere o método de correção dos limites de gastos que ali se está a instituir.

7 A inclusão do ideário de responsabilidade fiscal e controle da execução orçamentária como aspectos integrantes do Direito Financeiro como um todo, ao lado da tradicional cogitação em torno da despesa, receita, crédito público e orçamento era já apontada em FURTADO, J. R. Caldas. Elementos de Direito Financeiro. 2. ed. rev., ampl. e atual. Belo Horizonte: Editora Forum, 2010. p. 28.

8 É verdade que o art. 163, ICF já assinalava à lei complementar a disciplina das finanças públicas, figurando este mesmo preceito como fundamento à edição, por exemplo, da Lei de Responsabilidade Fiscal (Lei Complementar 101/00). Não é menos certo, porém, que essa abertura à densificação normativa por intermédio de lei complementar não impediria preceituação na matéria em sede constitucional.

9 A iniciativa se alinha com aquilo que Torres denomina reforma fiscal do Estado, traduzindo "alterações conjunturais das finanças públicas com a intenção de buscar o equilíbrio orçamentário ou corrigir desvios do 
fortes se têm enunciados na justificativa da então PEC 241/16.10 É esse mesmo marco da temporariedade que justifica inclusive, segundo a Mensagem que acompanhou à proposição, cuidar-se de alteração remetida ao Ato das Disposições Constitucionais Transitórias.

É de se dizer que a estratégia da regulação em sede de emenda constitucional, de matéria associada ao corpo permanente - mas não necessariamente derivada de alteração nessa mesma parcela estável do Texto Fundamental - não é inaugurada pela Emenda 95. Assim é que já a Emenda 3 de 1993, instituindo na sua primeira versão o IPMF (imposto sobre movimentação ou transmissão de valores e de créditos e direitos de natureza financeira) ${ }^{11}$, contemplava cláusula estranha ao texto original, e de vigência também pretensamente provisória. É verdade que naquela manifestação do poder constituinte reformador tinha-se alterações propostas ao corpo permanente da Constituição12, e ainda as inovações decorrentes dos preceitos do próprio texto da Emenda 3 em si, sem qualquer intervenção especificamente no ADCT - mas ali já se tinha inaugurada uma prática de aditar a normatividade de status constitucional, sem modificar o texto permanente da Carta de 1988.

A primeira alteração especificamente no corpo do ADCT para a inclusão de figuras de natureza temporária relacionada à disciplina das despesas públicas se deu com a Emenda de Revisão no 1 de 1994 que introduziu o art. 7113 na parte transitória da Constituição para a criação do Fundo Social de Emergência, "com o objetivo de saneamento financeiro da Fazenda Pública Federal e de estabilização econômica". Tem-se aqui já um afastamento da lógica doutrinária convencional no que toca ao conteúdo possível de preceitos insertos no ADCT.

Classicamente, este segmento de texto fundante destina-se à formulação de comandos que permitam a transição do regime jurídico anteriormente estabelecido,

sistema tributário", em oposição à reforma do Estado Fiscal, estas orientadas a alterações profundas na estrutura da fiscalidade, com o objetivo de superar os ranços do patrimonialismo que impedem o pleno florescimento da estatalidade" (TORRES, R. L. Tratado de Direito Constitucional, Financeiro e Tributário. Volume V - O orçamento na Constituição. 3. ed. Rio de Janeiro: Renovar, 2008. p. 40).

10 BRASIL. Proposta de Emenda à Constituição processada como Projeto de Emenda Constitucional $n^{\circ}$ 241/16. Altera o Ato das Disposições Constitucionais Transitórias, para instituir o Novo Regime Fiscal. Disponível em: <http://www.camara.gov.br/proposicoesWeb/fichadetramitacao?idProposicao=2088351>. Acesso em: 27 dez. 2016.

11 A referida espécie tributária hoje não mais vigente, foi criada pela Emenda 3 de 1993, e posteriormente substituída por contribuição provisória também sobre movimentação financeira traduzida pela Emenda 12 de 1996.

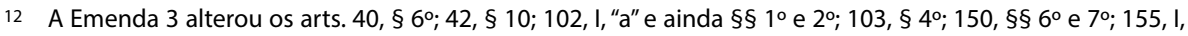
II e III bem como $\S \S 1^{\circ}, 2^{\circ}$ e $3^{\circ}$; 156 , III e seu $\S 3^{\circ}$, I, II e III; 160, Parágrafo Único; 167, IV e $\S 4^{\circ}$; todos da parte permanente da Constituição.

13 O texto original do ADCT encerrava-se no art. 70. 
para aquele que se tem por inaugurado com o novo Texto Constitucional. ${ }^{14}$ Nos sistemas que contemplam a possibilidade do exercício do poder constituinte reformador, tem-se como consectário lógico que também a passagem da velha ordem para o novo regime estabelecido por Emenda Constitucional possa oportunizar a formulação de cláusula transitória, com o mesmo papel viabilizador da conciliação da nova moldura normativa com interesses e situações que a principiologia própria ao Estado Democrático de Direito reclame sejam preservados em nome da segurança jurídica e da estabilidade das relações. Em ambas as acepções, o uso do ADCT como sede para alguma preceituação antes inexistente se relaciona à complementação da mudança havida no corpo permanente da Constituição pelo exercício do poder reformador.

A estratégia inaugurada pela Emenda de Revisão no 1 - de inclusão no ADCT de disciplina específica de tema financeiro, sem correspondente alteração no corpo permanente - se viu repetida inúmeras vezes. Boa parte destas iniciativas era associada ao financiamento de gastos públicos, seja pela criação de novas fontes de custeio da atividade pública em geral15, seja pela flexibilização do destino a ser conferido no plano da execução orçamentária às receitas efetivamente arrecadadas ${ }^{16}$, seja pela vinculação de receitas a atividades específicas, destinatárias de um especial signo de valoração constitucional. 17 Manifestação clara do uso permanente da reconfiguração do ADCT como leito de veiculação de iniciativas relacionadas às finanças públicas está no incessante processo de expansão deste mesmo segmento constitucional, que com a Emenda 95 alcança já 114 artigos - 44 a mais do que seu conjunto original de 70 preceitos.

Nesse sentido, a Emenda Constitucional 95 não inova propriamente enquanto estratégia de disciplina de matéria constitucionalizada, reproduzindo um fenômeno já antes identificado de múltiplas iniciativas de reforma da Carta de 1988 que se orientaram à matéria financeira, e em última análise, ao financiamento do extenso conjunto de deveres positivos de agir que o vasto elenco de direitos fundamentais reclama dos entes federados. ${ }^{18} \mathrm{Na}$ verdade, o perfil temporal dessas mesmas intervenções por Emenda,

14 SARLET, I. W.; MARINONI, L. G. e MITIDIERO, D. Curso de Direito Constitucional. São Paulo: Editora Revista dos Tribunais, 2012. p. 70.

15 No campo do provimento de novas fontes de financiamento, cite-se a Emenda 12 de 1996, que acrescentando o art. 74 ao ADCT criou a contribuição provisória sobre movimentação ou transmissão de valores e de créditos e direitos de natureza financeira; inovação revitalizada na sua limitação temporal originária pela Emenda 37 de 2002.

16 O exemplo clássico desse tipo de alteração normativa está na Emenda 68 de 2011, que instituindo a desvinculação das receitas da União (DRU), foi revitalizada e expandida pela Emenda 93 de 2015, agora cogitando igualmente da desvinculação de receitas no âmbito de Estados e Municípios.

17 Nesse campo são inúmeros os exemplos: 1) Fundo Social de Emergência, materializada pela Emenda de Revisão n० 1; 2) Fundo de Combate e Erradicação da Pobreza enunciada pela Emenda 31 de 2000, revitalizada pela Emenda 42 de 2003 e ainda a Emenda 67 de 2010; 3) FUNDEF, instituído pela Emenda 14 de 1996, e redesenhado como FUNDEB pela Emenda 56 de 2003.

18 VALLE, V.R.L. Transição política e construtivismo constitucional: uma análise empírica das emendas constitucionais brasileiras. In: CAMARGO, M. M. L.; LOIS, C. C.; MARQUES, G. L. (Org.). Democracia e jurisdição: novas 
vocacionadas ao financiamento da atividade pública reflete a curva de intensificação das demandas (judiciais inclusive) de efetivação dos direitos fundamentais contemplados na Constituição. Tem-se, portanto, nesse esforço de ampliação e direcionamento das fontes de financiamento, uma resposta às pressões de real oferta de bens e serviços decorrentes da dimensão objetiva dos direitos fundamentais.

Segunda observação de caráter mais genérico que se impõe formular diz respeito ao alinhamento da Emenda 95 com a estratégia já antes denunciada por Couto19, de constitucionalização de políticas públicas como mecanismo de constrição de gestões futuras, que para modificar o paradigma estabelecido por seu antecessor no jogo de alternância do poder, ver-se-ão forçadas a, quando menos, promover seu próprio processo de reforma constitucional, com todos os custos inerentes a este tipo de iniciativa num modelo de constitucionalismo de coalisão. A opção pelo teto de gastos no modelo proposto aplica-se sem possibilidade de alteração (salvo, evidentemente, nova emenda) por pelo menos 10 (dez) anos, nos termos do art. 108 do ADCT - e mesmo depois disso, a modificação no critério de atualização dos limites de gastos sujeita-se à cláusula de limitação de uma única proposição por mandato.

Decerto a instituição do Novo Regime Fiscal por meio de emenda constitucional decorre dos componentes que dizem respeito, seja às vinculações de receita anteriormente estabelecidas, seja às sensíveis relações no plano da disciplina fiscal, com as estruturas de contrapoder20 revestidas de autonomia financeira21. Afinal, o tema específico dos efeitos da autonomia financeira sobre as relações entre poderes já foi visitado por diversas vezes pelo Supremo Tribunal Federal, e a proposta externada na Emenda 95, embora não expresse propriamente uma correção legislativa de jurisprudência, decerto provocará a reaproximação a essas anteriores decisões, como de resto se vê já pelos termos da ADIN 5633.

Útil para prosseguir na análise, um percurso ainda que genérico, à estrutura proposta pelo Novo Regime Fiscal. É o que se desenvolve na sequência.

configurações brasileiras. Rio de Janeiro: Imo's Graf. e Ed., 2013. p. 331-360.

19 COUTO, Cláudio G.; ABRUCIO, Fernando. O segundo governo FHC: coalizões, agendas e instituições. Tempo social. São Paulo, v. 15, n. 2, 2003. Disponível em: < http://www.scielo.br/scielo.php?script=sci_arttext\&pid=S010320702003000200011\&lissoen\&nrm=iso >. Acesso em: 27 fev. 2009.

20 A expressão aqui se utiliza no sentido preconizado por Moreira Neto, que alude àquelas estruturas institucionais que, inseridas na organização formal do poder político, ali se apresentam como canais de vocalização de interesses da sociedade em geral - e não do projeto político que ocupe temporariamente a Chefia de cada qual dos seus braços especializados (MOREIRA NETO, Diogo de Figueiredo. Democracia e contrapoderes. Revista de Direito Administrativo, Belo Horizonte, n. 258, p. 47-80, set./dez. 2011).

21 Registre-se a perspectiva de Scaff, de que várias das limitações aos gastos federais trazidas pela Emenda 95 já exsurgiam da própria Carta de Base, ou ainda de outras normas jurídicas, cuja eficácia se viu em alguma medida comprometida por falta de vontade política, ou ainda por outros interesses corporativos (SCAFF, F. F. Retrospectiva 2016: "Farinha pouca, meu pirão primeiro" e a overdose de Direito Financeiro. Consultor Jurídico, São Paulo, dez. 2016. Disponível em: < http://www.conjur.com.br/2016-dez-27/retrospectiva-2016-farinha-meu-pirao-primeiro-overdose-direito-financeiro>. Acesso em: 28 dez. 2016. 


\section{DESENHO GERAL DE CONTEÚDO DA EMENDA 95}

O eixo principal da proposição hoje convertida na Emenda 95 é a instituição de um teto de gastos públicos, como mecanismo inibidor de um desequilíbrio de contas que se diagnostica como endêmico, comprometendo não só ao desempenho em si da Administração Federal, mas o quadro econômico em geral. A opção, a essa altura, se dá a partir de critério objetivo de limite nominal de dispêndios - por isso o recurso à expressão de sentido comum, "teto de gastos". Tal elemento de constrição da despesa pública se pretendeu estabelecer por prazo determinado (vinte anos) ${ }^{22}$, interstício esse que se julgou suficiente à promoção do reequilíbrio do padrão de gastos que se vinha desenvolvendo em curva progressiva.

A fixação do pretendido teto de gastos por período determinado envolveria a necessária delimitação de outros parâmetros como: 1) componentes relacionados ao cálculo desse patamar máximo autorizado; 2) critérios de atualização desse mesmo limite nominal no interstício de tempo previsto para sua vigência; 3) mecanismos de transparência em relação à observância do referido teto por ocasião da aprovação dos componentes da tríade orçamentária, em especial, LDO e LOA; 4) cominação de consequências para a eventual ultrapassagem do valor máximo autorizado de despesas. Sem estes parâmetros, não haveria como operacionalizar o cálculo do limite de dispêndio, no início e em cada qual dos vinte anos do Novo Regime Fiscal; e menos ainda como dar consequência às eventuais violações a essa mesma nova disciplina.

Integra ainda o corpo da Emenda 95, um conjunto de regras intermediárias, atinentes à compensação de despesas entre as unidades submetidas ao "teto". Isso porque a perspectiva de gastos para a execução orçamentária de 2017 pode apresentar uma virtualidade à violação aos limites fixados já em dezembro de 2016, e o constituinte reformador entendeu de prover parâmetros para esse eventual ajuste, caso ele venha a ser mostrar necessário.

\subsection{A fixação do limite de gastos}

Nesse esforço de densificação do Novo Regime Fiscal, tem-se a opção empreendida pela Emenda 95 de valer-se de limites individualizados (art. 107 do ADCT) tendo em contas as várias estruturas institucionais que se poderia identificar em cada qual dos poderes da República. Distancia-se assim a Emenda 95 de fórmulas anteriores já utilizadas na tentativa de fixação de limites de gastos, como a repetida iniciativa de contenção de despesas de pessoal, que tem na Lei Complementar 101/00 a sua última expressão normativa. Assim é que, se a primeva Lei Complementar 82/95 fixava um

22 A cláusula de limitação temporal inaugura a disciplina do Novo Regime Fiscal, enunciada que está no art. 106 introduzido ao ADCT pela Emenda 95. 
limite máximo de gastos com pessoal único para todos os níveis federados sem distinguir entre os diversos poderes, a Lei Complementar 96/05 seguia o mesmo modelo de limite único por poder, ainda com uma cláusula de responsabilidade solidária entre todos eles no cumprimento do referido patamar máximo.23 Só com a promulgação da Lei Complementar 101/00 se passa a ter o apontamento específico de limites de gastos por poder24, ainda assim, sem distinguir as subestruturas que cada destes braços especializados contivesse entre si. Tal agregação num mesmo limite, de instituições revestidas de prerrogativas próprias, culminou por gerar uma concorrência interna indesejável no que toca ao compartilhamento de recursos orçamentários 25 , e uma opacidade no que toca ao verdadeiro foco do eventual acréscimo indesejável no gasto de pessoal.

Nessa linha, adota a Emenda 95 a figura do limite individualizado de gastos, refletindo em cada qual dos incisos do art. 107 do ADCT, não só as diversas instituições revestidas de autonomia orçamentária, mas também os subsegmentos que elas possam apresentar. Observe-se que essa ampliação na segmentação dos limites de gastos para contemplar não só as instituições revestidas de autonomia orçamentária (Legislativo, Judiciário, Ministério Público e Defensoria Pública) mas também outras subdivisões institucionais existentes (CNJ, Conselho Nacional do Ministério Público, além dos diversos segmentos distintos de justiça especializada contido no inciso II do referido art. 107 $\mathrm{ADCT}$ ) não apresenta na Mensagem uma justificativa objetiva claramente posta26, e

23 Lei Complementar 96/05 - Art. 90 "Ficam os Poderes Executivo, Legislativo e Judiciário solidários no cumprimento dos limites estabelecidos no art. 10, sujeitando-se às eventuais reduções de despesas totais com pessoal."

24 A viabilidade constitucional da repartição de limites entre os poderes no que toca às despesas de pessoal foi examinada pela Corte por ocasião do controle em abstrato da Lei Complementar 101/00 (BRASIL. Supremo Tribunal Federal. ADI 2238 MC, Relator(a): Min. ILMAR GALVÃO, Tribunal Pleno, julgado em 09/08/2007, DJe172 DIVULG 11-09-2008 PUBLIC 12-09-2008 EMENT VOL-02332-01 PP-00024 RTJ VOL-00207-03 PP-00950). Na ocasião, impugnava-se o art. 20 da LRF que empreende exatamente à fixação de teto máximo de gasto por poder, ao argumento de que a fixação de limites específicos para cada qual dos poderes não se extraia da literalidade do art. $169 \mathrm{CF}$, e ainda de que se teria conflito insuperável com a autonomia orçamentária preconizada pelo art. $99 \S 1^{\circ} \mathrm{CF}$. A tese foi repudiada pela Corte por maioria, afirmando-se na ementa da decisão, no particular, que "o art. 169 da Carta Magna não veda que se faça uma distribuição entre os Poderes dos limites de despesa com pessoal; ao contrário, para tornar eficaz o limite, há de se dividir internamente as responsabilidades."

25 Em seu voto que inaugurou a divergência vencedora no debate em torno dos termos do art. 20 da Lei Complementar 101/00, que fixava limites por Poder para as despesas de pessoal, o Ministro Nelson Jobim já assinalava: ".... Tivemos duas leis Camata, a de n 82 e a primitiva. Todas essas leis tratam deste problema, já que se estabeleceu uma espécie de "bill" de indenidade para alguns Poderes, no tocante à responsabilidade fiscal. Então, enquanto um dos Poderes buscava uma determinada situação, porque era onerado na redistribuição das receitas nacionais, o outro gastava a verba. Criou-se, portanto, um imenso conflito" BRASIL. Supremo Tribunal Federal. ADI 2238 MC, Relator(a): Min. ILMAR GALVÃO, Tribunal Pleno, julgado em 09/08/2007, DJe-172 DIVULG 11-09-2008 PUBLIC 12-09-2008 EMENT VOL-02332-01 PP-00024 RTJ VOL-00207-03 PP-00950, Voto do Ministro Nelson Jobim, p. 98).

26 A rigor, a proposta original da PEC 241 aludia à fixação dos limites individualizados, referindo puramente aos poderes e órgãos dotados de autonomia financeira. A segmentação do Judiciário, e ainda dos Conselhos Nacional de Justiça e do Ministério Público deu-se no curso do processamento legislativo, já sendo esse o texto expresso na Proposta de Redação para o Segundo Turno de Discussão da PEC 241-C/16. 
parece se relacionar com a possibilidade de reduzir o eventual âmbito de incidência das medidas de constrição associadas à violação ao teto de gastos.

No que toca à definição de qual seja a base inicial para a apuração do limite de gastos, o art. 107, § 10, I do ADCT se vale do critério da despesa primária 27 paga no exercício de 2016, incluídos os restos a pagar28, corrigida em 7,2\% (sete inteiros e dois décimos por cento). Esta mesma fórmula de apuração (inclusão dos restos a pagar) se tem por extensível a todos os exercícios integrantes do insterstício de aplicação do Novo Regime Fiscal, nos termos da cláusula contida no § 10 do art. 107 incluído no ADCT pela Emenda 95.

Para fins da apuração do teto inicial, o critério envolveu o ano civil, eis que o exercício orçamentário obedece a essa mesma configuração. Já no que toca à atualização do patamar máximo de gastos para os exercícios subsequentes, a Emenda 95 adota o critério da variação do IPCA apurado por um período de doze meses, encerrado em junho do exercício anterior a que se refira a lei orçamentária. Tem-se aí uma inevitável diferenciação na perspectiva do recorte temporal - o primeiro período de apuração correspondente ao ano civil, e os demais compreendendo doze meses encerrando-se em junho. Diz-se inevitável a diferenciação porque a projeção do teto de gastos haveria de se ter por suscetível de delimitação em momento hábil a viabilizar a elaboração da proposta orçamentária, de modo que a solução proposta pela Emenda 95 parece a alternativa que mais aproxima essa atividade de proposição dos critérios da atividade financeira da União da realidade apurada do cenário econômico.

Exclui-se da base de cálculo (e por via de consequência, da incidência do limite de gastos) um conjunto de hipóteses elencadas no art. 107, § $6^{\mathrm{a}}$ do ADCT, introduzido pela Emenda 95.

Primeiro conjunto de situações contidas na referida cláusula de exclusão são as transferências constitucionais estabelecidas no art. 20, § $1^{\circ}$ (vulgarmente identificadas como royalties de petróleo29); art. 146, Parágrafo Único, III (transferências decorrentes

27 O conceito de despesa primária, expresso no Glossário do orçamento federal compreende "...aquelas que pressionam o resultado primário, alterando o endividamento líquido do Governo (setor público não financeiro) no exercício financeiro correspondente", e se opõe às despesas não primárias, que "...são aquelas que não pressionam o resultado primário ou não alteram o endividamento líquido do Governo (setor público não financeiro) no exercício financeiro correspondente, uma vez que criam um direito ou extinguem uma obrigação, ambas de natureza financeira, junto ao setor privado interno e/ou externo". BRASIL. Ministério do Planejamento, Orçamento e Gestão. Secretaria de Orçamento Federal. Disponível em: < http://www.orcamentofederal.gov.br/glossario-1/ glossario_view?letra=D>. Acesso em: 28 dez. 2016.

28 Parece acertada a opção de reconhecer a existência da figura dos restos a pagar como uma realidade da execução orçamentária, que onera o exercício subsequente, num efeito circular que não pode ser desconhecido.

29 Registre-se aqui a divergência entre a dicção adotada pela Emenda 95, que alude a transferências como gênero de todas as hipóteses contidas no preceituado no art. 107, § $6^{\circ} \mathrm{ADCT}$, sendo certo que no caso específico dos royalties de petróleo, a jurisprudência do STF já se firmou no sentido de proclamar não se cuide de transferências, mas de receita originária de Estados e Municípios. No tema consulte-se BRASIL. Supremo Tribunal Federal. MS 24312, Relator(a): Min. ELLEN GRACIE, Tribunal Pleno, julgado em 19/02/2003, DJ 19-12-2003 
do recolhimento unificado de tributos no regime diferenciado das microempresas); art. $153, \S 5^{\circ}$ (transferências decorrentes de operação com ouro qualificada como ativo financeiro ou cambial); art. 157, I e II, 158 e 159 (fundos de participação de Estados e Municípios); e ainda $212, \S 6^{\circ}$ (transferências relacionadas à contribuição social sobre o salário-educação). Excluem-se igualmente as transferências destinadas à assistência financeira ao Distrito Federal (art. 21, XIV), e a complementação do FUNDEB empreendida pela União (art. 60, V e VII do caput do art. 60 d0 ADCT). Parece lógica a cláusula que excepciona da constrição aos gastos transferências desenhadas pela Carta de 1988 no intrincado jogo de financiamento de atividades desenvolvidas sob o signo do federalismo de cooperação. Reconfigurar essas hipóteses de financiamento (também) pela União dos referidos gastos importaria em necessariamente redesenhar igualmente a responsabilidade pela execução dessas mesmas atividades, intervenção por certo muito mais ampla e espinhosa do que a que se pretendeu empreender com a Emenda 95.

Segunda exclusão da base de cálculo, portanto, do teto de gastos, são os créditos extraordinários previstos no art. $167, \S 3^{\circ} \mathrm{CF}$, a saber, aqueles destinados ao atendimento a "despesas imprevisíveis e urgentes, como as decorrentes de guerra, comoção interna ou calamidade pública". Também nesta hipótese, a exclusão é intuitiva, eis que o atendimento a situações deste cariz não se subordina à lógica da contenção de despesas.

A terceira hipótese de exclusão da base de cálculo e dos limites do teto de gastos diz respeito às despesas não recorrentes da Justiça Eleitoral com a realização das eleições - exceção que parece encontrar fundamento na cláusula pétrea protetiva do sufrágio contemplada no art. 60, § 4 , II CF. Cumpre assinalar que a expressão "despesas não recorrentes" não tem definição normativa na Lei 4320/64 ou outro instrumento regulador da contabilidade. Seu conceito, uma vez mais, é intuitivo, e se relaciona à não reiteração da mesma despesa - portanto, ao enfrentamento de algo que não se vincula ao dispêndio associado à operacionalidade ordinária da Justiça Eleitoral. O problema está em que a fluidez conceitual abre espaço à subjetividade na qualificação de despesas associadas à realização das eleições. O tempo dirá dos efeitos dessa abertura na textura normativa.

Quarta e última hipótese de exceção se tem nas despesas com aumento de capital de empresas estatais não dependentes. No campo estritamente jurídico, a expressão "empresas estatais não dependentes" não guarda correspondência no texto constitucional. A única cláusula do Texto de Base que se aproxima dessa mesma lógica, é aquela contida no art. $37, \S 9^{\circ} \mathrm{CF}$, que faz incidir o limite remuneratório às "empresas públicas e às sociedades de economia mista, e suas subsidiárias, que receberem

PP-00050 EMENT VOL-02137-02 PP-00350; e ainda BRASIL. Supremo Tribunal Federal, Al 453025 AgR, Relator(a): Min. GILMAR MENDES, Segunda Turma, julgado em 09/05/2006, DJ 09-06-2006 PP-00028 EMENT VOL02236-04 PP-00646 RTJ VOL-00201-01 PP-00367). 
recursos da União, dos Estados, do Distrito Federal ou dos Municípios para pagamento de despesas de pessoal ou de custeio em geral". O conceito em si de empresa dependente se teve por enunciado na Lei Complementar 101/00 que em seu art. $2^{\circ}$, III define empresa estatal dependente como aquela "controlada que receba do ente controlador recursos financeiros para pagamento de despesas com pessoal ou de custeio em geral ou de capital, excluídos, no último caso, aqueles provenientes de aumento de participação acionária". Esta mesma definição empreendida pela Lei de Responsabilidade Fiscal, é incorporado pela Lei 13.303/16 (Lei das Estatais), em seu art. 1º, § $2^{\circ}$.

A lógica é distinguir-se as empresas estatais que autofinanciam suas atividades ordinárias (pessoal e custeio) e mesmo outros dispêndios relacionados ao desenvolvimento de sua ação empresarial; daquelas que em qualquer das três hipóteses, revela-se dependente do aporte de recursos pelo controlador. Um elemento não resolvido pela dicção da Lei de Responsabilidade Fiscal é a frequência com que a necessidade de aporte de recursos do controlador em qualquer das espécies de despesa (pessoal, custeio ou capital) caracteriza efetivamente dependência. Essa zona cinzenta remanescerá no que toca à identificação das operações destinatárias da exclusão da base de cálculo do "teto" de gastos, isso porque embora a incidência em si em despesa com aumento de capital seja por óbvio, um episódio pontual, o mesmo não se pode afirmar em relação ao socorro financeiro pelo controlador que confere à entidade empresarial o atributo de empresa estatal dependente. Assim, o primeiro componente do preceito excepcional ("despesas com aumento de capital") tem-se por delimitado com relativa facilidade, seja pela formalidade de que ele se reveste, seja pelo seu caráter instantâneo. Já o segundo componente da hipótese de exclusão (empresas estatais não dependentes) está a carecer da delimitação já referida, de qual seja a frequência do auxílio empreendido pelo controlador que descaracterize a independência da entidade empresarial. Uma vez mais, abre-se espaço para algum subjetivismo na identificação de uma determinada operação de aumento de capital, como excluída da base de cálculo do teto de gastos.

Observe-se que o limite de dispêndio, apurado na forma do art. 107, § $1^{\circ}$, I e atualizado conforme o preceituado pelo art. 107, $\S 1^{\circ}$, II, ambos do ADCT, se tem posto como referencial máximo também aos critérios a serem estabelecidos pela Lei de Diretrizes Orçamentárias para a delimitação das propostas de meios em favor das instituições de contrapoder revestidas de autonomia.30 Tem-se aqui revelada uma preocupação sistêmica da Emenda 95 em estabelecer o teto de gastos para limite à deliberação tanto da entidade revestida de autonomia (que não poderá formular proposta orçamentária além desse parâmetro), quando ao titular do Executivo à época (que não

30 A alusão aos critérios fixados na LDO como limite à proposição orçamentária dos órgãos revestidos de autonomia se tem nos arts. 51, caput, inciso IV; 52, caput, inciso XIII; 99, § 10; 129, § 30; e 134, § $3^{\text {a }}$ da CF. 
poderá desenvolver nenhuma "concessão bondosa" em favor destas mesmas estruturas) e também ao Poder Legislativo, que na aprovação da Lei de Diretrizes Orçamentárias não poderá afastar-se do critério agora constitucionalizado.

\subsection{A atualização do limite de gastos}

Considerando a possibilidade de um distanciamento entre o índice de atualização previsto e a realidade socioeconômica sobre a qual incide a ação estatal no período originalmente fixado para vigência do Novo Regime Fiscal, a Emenda 95 prevê a possibilidade, transcorrido a primeira década de vigência, da revisão do "método de correção dos limites" fixado no art. 107, § 10, II do ADCT. Isso compreende a possibilidade em tese de eleição de outro índice que não o IPCA, e ainda a de fixação de outro período de apuração.

O dispositivo nasce polêmico, eis que nesse ponto se tem uma inequívoca distinção entre os poderes no que toca à aplicação do Novo Regime Fiscal. Assim é que se as constrições originais se estabeleceram ab initio de maneira homogênea em relação a todos os poderes; a possibilidade de alteração do método de correção destes mesmos limites se tem concentrada no Executivo. Peculiar ainda se revela o preceito contido no Parágrafo Único do art. 108 do ADCT, que restringe a possibilidade da alteração disciplinada no caput a uma única iniciativa por mandato. Se o fenômeno que o preceito pretende reconhecer e incorporar no sistema que disciplina é a dinâmica da realidade econômica, parece peculiar associar as potenciais medidas corretivas requeridas por essa mesma dinâmica a um dado que é estranho a esta realidade, a saber, o mandato do Chefe do Poder Executivo.

\subsection{Mecanismos de transparência associados ao Novo Regime Fiscal}

O monitoramento da estrita observância dos termos do Novo Regime Fiscal se tem por reforçado em distintos preceitos da Emenda 95, como o art. 107, § $3^{\circ}$ ADCT (que exige a demonstração da observância dos limites na mensagem que encaminha a proposta de lei orçamentária); o art. 113 ADCT (que exige a estimativa de impacto orçamentário e financeiro de proposições legislativas que criem ou alterem despesa obrigatória ou renúncia de receita); e ainda o art. 114 ADCT (que autoriza a suspensão de tramitação de proposição legislativa, em circunstância determinadas, para a apuração de sua compatibilidade com o Novo Regime Fiscal.

Neste conjunto de preceitos, orientado primariamente a conferir-se maior transparência à execução do novo regime de gastos, a dúvida maior se põe em relação ao sentido do art. $113 \mathrm{ADCT}$ - que mais uma vez usa expressão sem correspondente constitucional, a saber, "despesa obrigatória". Também nessa matéria, a referência legislativa 
de que se dispõe é o art. 17 da Lei Complementar 101/00, que conceitua despesa obrigatória de caráter continuado como aquela "despesa corrente derivada de lei, medida provisória ou ato administrativo normativo que fixem para o ente a obrigação legal de sua execução por um período superior a dois exercícios". O quadro de espécies de despesas contempladas pela Lei de Responsabilidade Fiscal se completa com a previsão do art. 16 do mesmo diploma, que tem em conta gastos que não observam o perfil temporal alongado sugerido pelo art. 17 - mas que podem se revelar igualmente relevantes do ponto de vista de gestão pública. Uma interpretação teleológica há de fazer conter no dever de demonstração de compatibilidade com o Novo Regime Fiscal preconizado pelo art. $113 \mathrm{ADCT}$, toda e qualquer despesa encartada em proposição normativa - ainda que não caracterizada como de caráter continuado.

\subsection{Efeitos jurídicos da violação dos limites fixados}

Último grande conjunto de preceitos contido na Emenda 95 diz respeito aos efeitos da violação aos limites ao longo do período de vigência do Novo Regime Fiscal.

Uma vez mais vem à tona o perverso dilema do que se estabelecer como consequência a uma gestão administrativa e fiscal que conduz ao desequilíbrio das contas públicas. Isso porque se de um lado existe a prática de possíveis ilícitos fiscais, administrativos e mesmo criminais de parte do gestor público envolvido; de outro lado o fato objetivo de um crescimento de despesas que não se revela sustentável subsiste - e esse é um mal a se atacar, tanto quanto a impunidade de gestores públicos dessintonizados com as boas práticas em finanças e gestão pública. $O$ resultado é que nas consequências ao quadro de desequilíbrio fiscal normalmente se põe sobre o desenvolvimento das atividades administrativas, com uma forte possibilidade de comprometimento em algum nível, dos serviços públicos desenvolvidos ou que deveriam se desenvolver.

Prova disso se tem na ênfase (no que toca às vedações decorrentes de descumprimento do teto de gastos) para com medidas de toda ordem, relacionadas aos servidores públicos e suas estruturas de carreira e remuneração enunciadas no art. 109, I a VI e $\S 3^{\circ}$ ADCT.

Duas observações merecem nota no que toca a estas vedações. Primeira delas diz com a quebra da lógica do ideário de limites individualizados, verificada duplamente nesse plano das consequências. Isso porque se o patamar máximo de gasto é de se estabelecer tendo em conta cada qual das estruturas referidas no art. 107, I a V; as consequências do seu descumprimento aplicam-se ao conjunto de órgãos referidos em cada inciso - o que retoma a lógica própria da fixação de limite por poder, e não por estrutura institucional que nele se contenha. $O$ problema se manifesta de maneira mais evidente no que diz respeito do Judiciário, que contém pelo menos 8 (oito) distintos segmentos abrigados no inciso II do art. 107 CF. Segundo e mais grave afastamento 
da lógica do limite individualizado se tem no art. 109, § $3^{\circ} \mathrm{ADCT}$, que no caso de descumprimento por qualquer dos integrantes do sistema, veda tout court a realização da revisão geral anual prevista no inciso $X$ do art. 37, caput CF.

É certo que a segmentação das estruturas orgânicas estatais para fins de vedação da revisão geral anual, limitando essa proibição àquela que tivesse empreendido à violação do limite individualizado de gastos, descaracterizaria a revisão como geral, subvertendo a lógico do art. 37, X CF. De outro lado, o compartilhamento dos ônus da má gestão financeira tende a gerar, um olhar um pouco mais complacente na apuração de uma eventual violação - de molde a evitar justamente a incidência de penalidades sobre a estrutura que se manteve fiel aos seus próprios limites.

Segunda observação no que toca à disciplina das consequências da violação ao teto de gastos diz respeito, uma vez mais, à não inclusão de vedação às despesas que não se revelem de cunho obrigatório. Essa pode ser uma abertura a permitir a realização de despesas de investimento que embora não se enquadrem na categoria vedada pelo art. 109, § 10, VII e VIII ADCT, uma vez mais, podem ter impacto financeiro que justifique o seu bloqueio. Despesas de capital, no conceito enunciado pela Lei 4320/64, tendem a se converter em despesas de custeio no futuro - e essa circunstância não deveria ter sido desconsiderada.

Vale ainda comentar a preocupação externada no art. 109, § $4^{\circ}$ do ADCT, em explicitar que as vedações enunciadas nos incisos desse mesmo preceito se punham igualmente às proposições legislativas. Não se cuida de uma tautologia do constituinte reformador, mas de abrir-se a possibilidade de exercício facilitado do controle abstrato de constitucionalidade de normas que eventualmente pretendam, em nome de uma suposta expressão da soberania popular, contornar a proposta de fixação real de limites de gastos.

Esse o quadro geral dos comandos enunciados pela Emenda 95, que tem já atraído intenso debate na perspectiva estritamente jurídica, no tema da violação ao equilíbrio e harmonia entre poderes, ao menos no que toca às medidas que constringem de alguma forma, as estruturas institucionais revestidas de autonomia. Impõe-se, para a formulação de qualquer juízo relacionado à constitucionalidade de tais preceitos, compreender os parâmetros que exsurgem da jurisprudência já consolidada no STF na seara dos efeitos das cláusulas constitucionais assecuratórias de autonomia orçamentária.

\section{AUTONOMIA FINANCEIRA E PRERROGATIVAS DELA DECOR- RENTES NA JURISPRUDÊNCIA DO STF}

Conhecidas são as razões que levam o Texto Constitucional a assegurar autonomia administrativa e financeira a estruturas integrantes do sistema de controle de juridicidade. Independência (e esse é um dado da vida) guarda estreita relação com meios 
de financiamento que confiram liberdade para a formulação de escolhas. Assim, não há que se aludir a Judiciário independente se não se revelar capaz de prover por seus próprios meios, o necessário quando menos ao seu funcionamento regular. Nesse sentido, assegura a Carta de 1988 em várias passagens já referidas neste texto, autonomia financeira ao Judiciário, Ministério Público e Defensoria Pública - esta última, por sua vez, conferida pelo exercício do poder constituinte reformador, com a Emenda 80/14.

Já em 1991 se encontra primeira manifestação do STF envolvendo o tema dos contornos da autonomia financeira, à época, do Judiciário. O debate se travava em torno de decisão administrativa manifesta pelo Tribunal Regional Federal da 2a Região, que determinava a inclusão na proposta orçamentária para o exercício de 1992, de valores atinentes ao pagamento do percentual de reajuste de $84,32 \%$ (que beneficiara alguns servidores, destinatários de decisão judicial) a todos os servidores daquela Corte, independentemente de ordem judicial neste sentido. A decisão administrativa, neste segmento que determinava o provisionamento de recursos orçamentários para o pagamento de reajuste não previsto em lei e não decorrente de medida judicial foi reputada inconstitucional, sem prejuízo do que deflui do art. 99 CF. ${ }^{31}$ Relevante indicativo se extrai da referida decisão, a saber, a autonomia administrativa e financeiro do Poder Judiciário não se revela absoluta, admitindo-se o controle judicial inclusive de ato normativo que extrapole os limites dessa mesma autonomia. 32

Neste mesmo ano de 1991, em acórdão da lavra do Ministro Celso de Mello33, o STF delimita o thelos da garantia constitucional de autonomia, tendo em conta ainda o Judiciário - mas por certo, a mesma matriz se aplicaria a todas as demais previsões constitucionais de idêntico teor. Dialogando agora com a cláusula contida no art. 168 CF atinente à entrega dos duodécimos às estruturas cratológicas revestidas de autonomia, assim diz a Corte:

O legislador constituinte, dando consequência a sua clara opção politica - verdadeira decisão fundamental concernente a independência da Magistratura instituiu, no art. 168 de nossa Carta Politica, uma típica garantia instrumental, assecuratória da autonomia financeira do Poder Judiciário. A norma inscrita no art. 168 da Constituição reveste-se de caráter tutelar, concebida que foi para impedir o Executivo de causar, em desfavor do Judiciário, do Legislativo e do Ministério Público, um estado de subordinação financeira que comprometesse,

31 BRASIL. Supremo Tribunal Federal. ADI 577 MC, Relator(a): Min. SEPÚLVEDA PERTENCE, Tribunal Pleno, julgado em 18/09/1991, DJ 18-10-1991 PP-14549 EMENT VOL-01638-01 PP-00123 RTJ VOL-00138-01 PP-00070.

32 Consigne-se que a cautela deferida no acórdão lançado na nota de rodapé n 26 foi confirmada em análise de mérito, na: BRASIL. Supremo Tribunal Federal. ADI 577, Relator(a): Min. OCTAVIO GALLOTTI, Tribunal Pleno, julgado em 25/10/1996, DJ 08-03-1996 PP-06213 EMENT VOL-01819-01 PP-00039.

33 BRASIL. Supremo Tribunal Federal. MS 21291 AgR-QO, Relator(a): Min. CELSO DE MELLO, Tribunal Pleno, julgado em 12/04/1991, DJ 20-10-1995 PP-36331 EMENT VOL-01805-02 PP-00201. 
pela gestão arbitraria do orçamento - ou, até mesmo, pela injusta recusa de liberar os recursos nele consignados -, a própria independência político-jurídica daquelas Instituições.

O elemento de subordinação apresenta-se, na leitura empreendida pela Corte, como a chave de solução para o exame dos efeitos jurídicos do reconhecimento da autonomia. O que se deseja evitar é a sujeição do controlador ao controlado - e por isso não é de se admitir desenvolva esse mesmo controlado, iniciativas que resultem numa subalternidade que se revelaria incompatível com o equilíbrio e harmonia, e ainda com a higidez de um sistema constitucional de controle da juridicidade, que tem no acesso à justiça relevante expressão. Ratificando a subordinação como elemento a caracterizar a violação à autonomia, tem-se ainda o reprocho enunciado pela Corte à tentativa de sujeição empreendida pela via transversa da vinculação a órgão do Executivo. ${ }^{34}$ Ainda na casuística da Corte tem-se a reafirmação da reserva de iniciativa contemplada no art. $99, \S 1^{\circ} \mathrm{CF} 35$ e a exigência da participação (em conjunto com os demais poderes) na elaboração da Lei de Diretrizes Orçamentárias. ${ }^{36}$

Importante observar que essa proclamação da reserva de iniciativa e da necessária participação na fixação dos limites a se conterem na Lei de Diretrizes Orçamentárias funciona como premissa para nova decisão, que confere coerência sistêmica aos precedentes. Assim, se a autonomia já se proclamara como um valor que não se põe como absoluto, a Corte vai afirmar seja a LDO a sede própria para a aplicação de medidas de contenção de gastos às estruturas institucionais revestidas de autonomia orçamentária. $37 \mathrm{O}$ tema volta à consideração do STF em outra controvérsia em torno

34 BRASIL. Supremo Tribunal Federal. ADI 3569, Relator(a): Min. SEPÚLVEDA PERTENCE, Tribunal Pleno, julgado em 02/04/2007, DJe-013 DIVULG 10-05-2007 PUBLIC 11-05-2007 DJ 11-05-2007 PP-00047 EMENT VOL02275-01 PP-00160 LEXSTF v. 29, n. 342, 2007, p. 96-105 e BRASIL. Supremo Tribunal Federal. ADI 3965, Relator(a): Min. CÁRMEN LÚCIA, Tribunal Pleno, julgado em 07/03/2012, ACÓRDÃO ELETRÔNICO DJe-065 DIVULG 29-03-2012 PUBLIC 30-03-2012 REVJMG v. 63, n. 200, 2012, p. 351-355.

35 BRASIL. Supremo Tribunal Federal. ADI 810 MC, Relator(a): Min. FRANCISCO REZEK, Tribunal Pleno, julgado em 10/12/1992, DJ 19-02-1993 PP-02032 EMENT VOL-01692-02 PP-00335.

36 BRASIL. Supremo Tribunal Federal. ADI 848 MC, Relator(a): Min. SEPÚLVEDA PERTENCE, Tribunal Pleno, julgado em 18/03/1993, DJ 16-04-1993 PP-06431 EMENT VOL-01699-02 PP-00348 e BRASIL. Supremo Tribunal Federal. 1911 MC, Relator(a): Min. ILMAR GALVÃO, Tribunal Pleno, julgado em 19/11/1998, DJ 12-03-1999 PP-00002 EMENT VOL-01942-01 PP-00113; ambas sem decisão de mérito, eis que tido o pedido principal por prejudicado pelo exaurimento dos efeitos da lei inicialmente impugnada. Indique-se ainda decisão de 2016: BRASIL. Supremo Tribunal Federal. ADI 5381 MC-Ref, Relator(a): Min. ROBERTO BARROSO, Tribunal Pleno, julgado em 18/05/2016, PROCESSO ELETRÔNICO DJe-256 DIVULG 30-11-2016 PUBLIC 01-12-2016.

37 BRASIL. Supremo Tribunal Federal. ADI 4356, Relator(a): Min. DIAS TOFFOLI, Tribunal Pleno, julgado em 09/02/2011, DJe-088 DIVULG 11-05-2011 PUBLIC 12-05-2011 EMENT VOL-02520-01 PP-00022; e ainda BRASIL. Supremo Tribunal Federal. ADPF 307 MC-Ref, Relator(a): Min. DIAS TOFFOLI, Tribunal Pleno, julgado em 19/12/2013, PROCESSO ELETRÔNICO DJe-060 DIVULG 26-03-2014 PUBLIC 27-03-2014. A solução aqui ofertada, é de se dizer, não é infensa à crítica, eis que a rigor, a elaboração da proposta orçamentária em desconformidade com os parâmetros da Lei de Diretrizes Orçamentárias (esse era o pano de fundo fático que deu ensejo à norma jurídica impugnada em abstrato) se constitui por si só, uma violação à Carta de Base. Este argumento fático, suscitado expressamente pela defesa, não restou examinado pela Corte, mas se tem por valorizado na 
do papel da LDO como parâmetro de elaboração, desta feita na ADI 528738, onde se debate uma vez mais o critério jurídico de solução para a intervenção pelo Executivo na proposta orçamentária dos entes revestidos de autonomia. Observe-se que na ocasião, o argumento do Executivo era exatamente de inobservância pelo proponente, dos limites da LDO - mas a apuração específica dessa circunstância objetiva restou perdida, na conjugação de vários outros temas que se punham como pretensa cláusula de bloqueio ao exercício do controle abstrato tendo em conta a norma jurídica especificamente impugnada.

Neste mesmo precedente, a par de admitir a ocorrência de medidas de contenção na negociação preconizada para fins de elaboração da LDO, afirma ainda a Corte que cabe ao Executivo, caso entenda inadequada ou incorreta a proposta orçamentária como apresentada pelo órgão autônomo, buscar a sua retificação no curso do processo legislativo.

Consigne-se ainda a afirmação já empreendida igualmente pelo STF de que a autonomia orçamentária não se assegura exclusivamente por ocasião da elaboração da proposta orçamentária, sendo ela igualmente aplicável no plano da execução da Lei de Meios. Essa afirmação, antes formulada no MS 21291 AgR-QO39 (feito de natureza subjetiva, sujeito a limites no que toca à sua aplicação por extensão), se viu reiterada na ADPF 33940, onde se tem, alinhado com a prática adotada pela Corte Constitucional de enunciação da tese jurídica consagrada, a seguinte proposição-síntese:

É dever constitucional do Poder Executivo o repasse, sob a forma de duodécimos e até o dia 20 de cada mês (art. 168 da CRFB/88), da integralidade dos recursos orçamentários destinados a outros Poderes e órgãos constitucionalmente autônomos, como o Ministério Público e a Defensoria Pública, conforme previsão da respectiva Lei Orçamentária Anual.

Curiosamente, no campo da execução orçamentária identifica-se ainda a reafirmação da autonomia na decisão havida em relação ao art. 9a ${ }^{a}$ § $3^{\circ}$ da Lei de Responsabilidade Fiscal. O conjunto preceitual enuncia o dever de proceder-se à limitação de empenho quando verificado um nível de realização das receitas que aponte para um possível comprometimento das metas de resultado primário contidas no Anexo

tese enunciada no acórdão - o que se constitui por si só, um paradoxo. Se a observância aos limites fixados pela LDO pelo órgão revestido de autonomia financeira se põe como um dever constitucional, o sistema há de oferecer resposta ao encaminhamento de proposta que não observe esse mesmo limite; e este resposta não pode ser submetida a um juízo de deliberação livre por parte do Legislativo.

38 BRASIL. Supremo Tribunal Federal. ADI 5287, Relator(a): Min. LUIZ FUX, Tribunal Pleno, julgado em 18/05/2016, PROCESSO ELETRÔNICO DJe-194 DIVULG 09-09-2016 PUBLIC 12-09-2016.

39 Vide nota de rodapé 28 acima.

40 BRASIL. Supremo Tribunal Federal. ADPF 339, Relator(a): Min. LUIZ FUX, Tribunal Pleno, julgado em 18/05/2016, PROCESSO ELETRÔNICO DJe-159 DIVULG 29-07-2016 PUBLIC 01-08-2016. 
de Metas Fiscais. A norma contida no caput assinalava o dever de empreender-se à referida medida de limitação à execução orçamentária a cada qual dos poderes e ainda ao Ministério Público; já o art. $9^{\circ}, \S 3^{\circ}$ da Lei Complementar 101/00 transferia ao Poder Executivo essa mesma competência na eventual omissão dos demais destinatários deste dever positivo de agir. A conclusão da Corte foi no sentido da existência sim, em relação a cada qual dos detentores de autonomia orçamentária, do dever positivo de agir consistente na limitação de empenho, declarando, porém, inconstitucional o § $3^{\circ}$ do multi citado art. $9^{\circ}$ da LRF por expressar interferência indevida do Executivo sobre os demais Poderes. O argumento então manejado - que ainda diz respeito à compreensão acerca da subordinação que a autonomia orçamentária pretende evitar - é de que não se poderia reconhecer no Poder Executivo a capacidade de identificar a violação e ao mesmo tempo, de empreender às medidas corretivas a ela associadas. 41

Merece alusão ainda, no campo de precedentes envolvendo o debate em torno da autonomia orçamentária, aquele havido na ADI 336742, onde se discutia a compatibilidade com o texto constitucional, da criação por intermédio da Emenda 45 de 2004, do Conselho Nacional de Justiça, que detém, na forma do art. 1'03-B, $\S 4^{\circ} \mathrm{CF}$, competência para o controle da atuação administrativa e financeira do Poder Judiciário. Naquela ocasião, sustentou-se justamente o desprestígio aos mesmos eixos do desenho institucional, a saber, autonomia financeira e separação dos poderes. A decisão, como se sabe, foi no sentido de rejeitar-se a imputação de vício de raiz, eis que as competência reconhecida ao CNJ não atingia, a ver do Min. Cezar Peluso, o "núcleo político do princípio", eis que preservada a função jurisdicional e as condições materiais do seu exercício imparcial e independente.

\footnotetext{
41 A ideia central então expressa pelo Ministro Sepúlveda Pertence, reportando-se a precedente anterior envolvendo a adoção pelo Governador de Estado de medidas de constrição em relação a outro poder foi de que "o Governador jamais poderia ser o julgador e o executor de uma eventual ilegalidade cometida por outro poder, que tem vias constitucionais próprias de impugnação (ADI-MC 691, 22.04.92, RTJ 140/797)." (BRASIL. Supremo Tribunal Federal. ADI 2238 MC, Relator(a): Min. ILMAR GALVÃO, Tribunal Pleno, julgado em 09/08/2007, DJe-172 DIVULG 11-09-2008 PUBLIC 12-09-2008 EMENT VOL-02332-01 PP-00024 RTJ VOL-00207-03 PP-00950, Voto do Ministro Sepúlveda Pertence, p. 170). A proposição de não interferência no curso da execução orçamentária nesse mesmo precedente, foi levada ao extremo pelo mesmo Ministro Sepúlveda Pertence, que ainda em seu voto, indagado pelo Ministro Nelson Jobim acerca de qual seria a providência a se desenvolver caso o Poder não empreendesse às medidas de limitação de empenho, respondeu: "Não sei. E se o Poder Executivo não cumprir, Ministro, como é que faz? [indagava de volta ao Ministro Nelson Jobim]. Isso se chama autonomia financeira, onde se podem cometer ilegalidades. Nenhum Poder será juiz do outro".

42 BRASIL. Supremo Tribunal Federal. ADI 3367, Relator(a): Min. CEZAR PELUSO, Tribunal Pleno, julgado em 13/04/2005, DJ 17-03-2006 PP-00004 EMENT VOL-02225-01 PP-00182 REPUBLICAÇÃO: DJ 22-09-2006 PP00029
} 
Último precedente que vale assinalar no tema da relação entre autonomia financeira e incidentes de execução orçamentária foi firmado nos MS 3167143 e 3448344; ambos versando sobre reivindicação de Judiciários Estaduais no sentido de cumprimento do dever de repasse dos duodécimos segundo o contido na previsão orçamentária original - e não conforme os termos do comportamento real da receita, que se mostrara inferior ao projetado. Nas duas hipóteses, a Corte entendeu de promover à conciliação entre os repasses duodecimais assegurados a cada qual dos Poderes e órgão revestidos de autonomia financeira, e o comportamento real dos ingressos, autorizando procedesse o Executivo à dedução do percentual apontado de frustração de arrecadação. ${ }^{45}$

Do percurso aos precedentes elencados é possível afirmar em resumo que: 1) a autonomia orçamentária das estruturas institucionais integrantes da estrutura de controle destina-se, na perspectiva finalística, a evitar um estado de subordinação em relação ao Poder Executivo; 2 ) esta mesma autonomia não se constitui em valor absoluto, sujeita que está a parâmetros objetivos no seu exercício, critérios esses que devem ser construídos mediante consensos possíveis e veiculados na Lei de Diretrizes Orçamentárias; 3 ) observados os referidos parâmetros objetivos delineados na LDO, não se reconhece ao Poder Executivo a formulação de juízo de valor sobre as escolhas materializadas na proposta orçamentária; 4) a fase de deliberação legislativa comportará a possibilidade de modificação do proposto, inclusive por força de gestões políticas do Executivo, observados os limites constitucionalmente estabelecidos no art. 166, §§ $3^{\circ}$ e $\left.4^{\circ} \mathrm{CF} ; 5\right)$ a autonomia orçamentária é de ser assegurada igualmente na fase de execução da Lei de Meios, sendo vedado ao Executivo empreender à retenção de duodécimos; e 6) o direito ao acesso aos duodécimos não se define exclusivamente a partir da previsão contida na Lei de Meios, mas é de sofrer os (eventuais) reflexos negativos da realidade econômica expressa em frustração da receita.

Cumpre agora o exercício de transposição destas mesmas premissas de raciocínio, ao debate já estabelecido quando menos na provocação ao controle abstrato de constitucionalidade, em relação aos termos da Emenda 95.

\section{AUTONOMIA ORÇAMENTÁRIA E SEPARAÇÃO DE PODERES: OS TEMAS PRIMÁRIOS DE DEBATE}

\footnotetext{
43 BRASIL. Supremo Tribunal Federal. MS 31.671, Relator(a): Min. RICARDO LEWANDOWSKY, Tribunal Pleno, reconfigurando medida liminar original em sessão de 09/10/2013, PROCESSO ELETRÔNICO DJe-207 DIVULG 17-10-2013 PUBLIC 18-12-2016.

44 BRASIL. Supremo Tribunal Federal. MS 34.483, Relator(a): Min. DIAS TOFFOLI, Tribunal Pleno, medida liminar reconfigurada pelo Plenário em sessão de 22/11/2016, PROCESSO ELETRÔNICO DJe-249 DIVULG 22-112016 PUBLIC 23-11-2016.

45 Consigne-se a cautela da Corte em ambos os precedentes, seja em demarcar a excepcionalidade da situação, seja em buscar a ratificação e a possibilidade de ajuste dos valores efetivamente identificados de queda da arrecadação.
} 
A judicialização já empreendida em torno da Emenda 95 na ADI 5633 aponta como fundamentos a violação aos arts. $2^{\circ} ; 60, \S 4^{\circ}$, III e 99 , todos da CF. A rigor o argumento se resume a dois, a saber, violação ao equilíbrio e harmonia entre poderes (art. $2^{\circ} \mathrm{CF}$ ), em si cláusula pétrea (art. 60, § 4, III CF); e violação à autonomia orçamentária reconhecida ao Judiciário. 46

\subsection{Novo Regime Fiscal e alegada violação à autonomia orça- mentária}

O primeiro argumento - da violação à autonomia orçamentária - parece o de mais fácil superação, especialmente quando se tem em conta os precedentes acima já percorridos.

O modelo constitucional original neste tema, prevê como eixos da autonomia financeira dos Tribunais a capacidade para elaborar suas próprias propostas (art. 99, § 10, ICF), observados limites fixados na LDO; e ainda a garantia do repasse dos duodécimos (art. 168 CF). Nenhum destes aspectos se tem por contaminado pelo Novo Regime Fiscal, que preserva a reserva de iniciativa e o dever de repasse dos duodécimos. O ponto mais sensível pode estar nos termos do art. 107, $\S 2^{\circ}$, que condiciona temporariamente os limites a serem fixados na LDO, ao teto de gastos instituído pela Emenda 95. Tem-se aqui uma cláusula de constrição ao resultado que poderia decorrer da "estipulação conjunta com outros poderes na Lei de Diretrizes Orçamentárias" - este não poderá ser superior ao teto de gastos ora instituído.

Para a solução da quaestio associada à constitucionalidade de tal cláusula restritiva, cumpre buscar aplicação do critério fixado pela jurisprudência acima referida, que reconhece a autonomia como blindagem contra a subordinação financeira empreendida por um Poder sobre o outro, capaz de comprometer a independência político-jurídica daquelas instituições.

A tese da impugnação em abstrato da norma está em que a teor do art. 99, $\S 1^{\circ} \mathrm{CF}$, a única sede possível para a fixação de limites ao exercício desta autonomia financeira seria a Lei de Diretrizes Orçamentárias, que por sua vez, haveria de se constituir a partir de "estipulação conjunta". Haveria impropriedade, portanto, na forma e na iniciativa do Novo Regime Fiscal, veiculado por Emenda de autoria do Poder Executivo.

Duas fragilidades imediatas se põem em relação ao argumento. Primeiro, afirmar possível o estabelecimento de limites ao exercício da proposição orçamentária pela via das Diretrizes Orçamentárias, e nega-lo na via do emendamento constitucional

46 Não se olvide o leitor da circunstância de que a ação abstrata foi manejada por associações vinculadas a distintos segmentos da magistratura, e portanto, à vista do requisito especial de legitimação ativa, seria de se observar o requisito de pertinência temática. A mesma matriz argumentativa, todavia, se poderia facilmente transpor, especialmente no exercício do controle abstrato, em favor das demais estruturas institucionais revestidas de autonomia orçamentária. 
é uma contradição em termos - a análise aqui se dá sob a perspectiva da pretensa violação à garantia de autonomia financeira.

É da essência do poder constituinte reformador, empreender à alteração de uma sistemática posta pelo texto original da constituição, subordinando-se tão-somente aos limites expressos nas cláusulas pétreas. Sustentar a inconstitucionalidade do acréscimo de parâmetro adicional temporário (teto de gastos) pela inobservância de uma estipulação conjunta, como a preconizada pelo art. 99, § 10, I CF, é negar ao poder reformador aquilo que é sua aptidão jurídica própria, a saber, harmonizar o Texto Fundamental com as tensões impostas pela realidade constitucional. 47

Segundo, autonomia orçamentária não é atributo institucional que se possa exercer à parte dos princípios constitucionais que orientam a atividade financeira do Estado. Assim, o princípio de equilíbrio orçamentário, verdadeira fonte de legitimação da ação estatal terá plena aplicação também no que diz respeito às instituições revestidas de autonomia - e para tanto, é de se recepcionar a possibilidade de, em nome deste mesmo princípio, desenvolver-se as medidas necessárias à equalização de receitas e gastos em toda a estrutura estatal.

Dialogando ainda com o conceito de autonomia financeira traçado pela jurisprudência constitucional, não se tem na fixação de um critério objetivo, matematicamente suscetível a teste e repetição, aplicável igualmente a todas as estruturas institucionais revestidas desta mesma autonomia, uma tentativa de sujeição capaz de comprometer a independência político-jurídica daquelas instituições. Afinal, é da essência do conceito de subordinação um vínculo de dependência que o subordinante impõe sobre o subordinado; e isso não decorre do art. 107 ADCT, vez que não obstante o limite nele fixado, a aptidão à formulação da proposta orçamentária - que compreende as escolhas relacionadas aos gastos ali autorizados - remanesce inteiramente assegurada às instituições dotadas de autonomia financeira, assim como a elas se preserva o direito ao acesso aos recursos, na forma preconizada pelo art. 168 CF. Significa dizer que as escolhas políticas subjacentes à decisão de gastar remanescem no âmbito das entidades autônomas, preservada a esfera de decidibilidade que é inerente a estas estruturas institucionais. 48

Observe-se ainda que o Novo Regime Fiscal não contempla na sua estrutura geral de aplicação, conferir-se ao Poder Executivo a possibilidade de formulação de juízo de valor em relação aos componentes em si da apuração e atualização do teto

47 É de Miranda a afirmação do caráter inelutável do fenômeno da modificação das Constituições; mudança essa se que dá reclamada pelas inadaptações supervenientes entre texto e realidade, que podem culminar por contribuir contra a efetividade constitucional. (MIRANDA, Jorge. Teoria do Estado e da Constituição. Rio de Janeiro: Forense, 2002. p. 389).

48 É de Oliveira a explicitação do caráter político das decisões relacionadas à materialização em si do da despesa pública (OLIVEIRA, R. F. de. Curso de Direito Financeiro. 7. ed. rev., atual. e ampl. São Paulo: Thomson Reuteures-Revista dos Tribunais, 2015. p. 451.). 
de gastos, ou menos ainda quanto às consequências da sua inobservância. Essa apreciação valorativa acerca das escolhas orçamentárias empreendidas pelas estruturas revestidas de autonomia, seja etapa de formulação das respectivas propostas, seja na de execução orçamentária se teve por vedada pela casuística acima noticiada no âmbito do STF - e esse padrão de preceituação não se tem no Novo Regime Fiscal.

A limitação material de recursos é um fato da vida, que não se pode entender como tentativa inconstitucional de subordinação, se ele se aplicar igualmente a todas as estruturas de poder - neste sentido as decisões referidas acima nos MS 31671 e 34483, que autorizando a redução do repasse dos duodécimos deduzidos da parcela correspondente à frustração da receita, empreendem à conciliação entre orçamentário e financeiro.

É certo que o Novo Regime Fiscal se revela ab initio como desconfortável barreira a pretensões de expansão de atividades desenvolvidas por estruturas revestidas de autonomia financeira - mas esta é meramente uma primeira (e equívoca) aproximação. Com o Novo Regime Fiscal, o que pode se apresentar como alternativa possível é o financiamento da expansão das atividades não pelo aumento nominal das despesas primárias, mas pela racionalização em geral do dispêndio, e o incremento da qualidade do gasto público.49

Remanesceria, do argumento da pertinência subjetiva da modificação constitucional - a saber, Emenda de iniciativa do Poder Executivo, que não foi precedida da estipulação conjunta, recomendada pelo art. 99, § 10, I CF. Considerados os limites formais subjetivos desenhados pelo art. 60 e seus incisos $C F$, a imputação de eventual vício de raiz se relacionaria à violação ao limite material explícito traduzido na cláusula de proteção ao princípio de equilíbrio e harmonia entre poderes. Essa a tese que se vai refutar na sequência.

\subsection{Novo Regime Fiscal e alegada violação ao equilíbrio e harmonia entre os poderes}

Em que pese o caráter verdadeiramente seminal da máxima do equilíbrio e harmonia entre poderes na engenharia constitucional, instrumental ao grande projeto de prevenção quanto aos abusos; inequívoca a indeterminação dessa mesma fórmula,

49 É de Graziane a advertência em relação ao real risco de inefetividade das soluções jurídicas construídas a partir do fetiche da norma, se não se tiver em conta o imperativo de aprimorar-se a qualidade do gasto público. (GRAZIANE, E. P. Sociedade que não planeja aceita a má qualidade do gasto público. Consultor Jurídico, São Paulo, dez. 2016. Disponível em: < http://www.conjur.com.br/2016-dez-06/contas-vista-sociedade-nao-planeja-aceita-ma-qualidade-gasto-publico>. Acesso em: 03 jan. 2017. 
sempre sensível às particularidades de seu tempo e da sociedade na qual essa mesma proposta se aplica. 50

Críticas tem se posto em relação à viabilidade mesmo da aplicação de uma concepção de equilíbrio e harmonia entre poderes na sua forma mais pura, sem qualquer intervenção entre os distintos corpos políticos a quem se tenha afeto as tradicionais funções executiva, legislativa e judiciária.51 Mais especificamente, a dúvida parece localizar-se em qual seja a mecânica mais adequada à real operação deste mesmo princípio. 52

A aproximação formal ao conteúdo do ideário de equilíbrio e harmonia entre poderes vincula-se à preservação da integridade na distribuição de funções de cada braço especializado. Esta concepção peca, de início, pela suposição de que haja uma distinção intrínseca entre as funções confiadas a cada estrutura institucional de poder - premissa artificial, que não resiste à fenomenologia própria à prática ordinária da aplicação constitucional. Já a aproximação funcional, reconhecendo o artificialismo da compartimentalização formal, assume as interações entre funções como uma possibilidade. Nessa visão, embora se parte de premissas mais harmônicas com a realidade, nem por isso se indicam parâmetros mais claros para aferir quando a interação deixa de ser instrumental à adequada aplicação do Texto de Base, e passa a caracterizar uma violação à separação de poderes. Parece, portanto, inevitável retomar a instrumentalidade do referido princípio para com ela avançar-se no delineamento de critérios para a sua proteção.

Explorando o mesmo tema, Ackerman aduz que a cláusula de separação de poderes concorre para o ideal de legitimação das decisões do poder - o que guarda a mais estreita harmonia com sua função de prevenção contra o abuso. Nessa linha, a evocação à separação de poderes contribuirá para a referida legitimação toda vez que servir ao ideal democrático de auto-governo; ao incremento da competência profissional em cada qual das funções; e finalmente, para a proteção e incremento do projeto de direitos humanos. 53

50 É de Piçarra a observação de que "o princípio constitucional da separação dos poderes não é prévio à constituição, mas constrói-se a partir dela" (PIÇARRA, N. A separação dos poderes como doutrina e princípio constitucional: Um contributo para o estudo das suas origens e evolução. Coimbra: Coimbra Editora Limitada, 1989. p. 16)

51 Jellinek já advertia que tão logo que queira transpor a doutrina da separação dos poderes à realidade, surgem dificuldades práticas e doutrinárias, as primeiras advindas do mundo da política; as segundas relacionadas ao modo de harmonização da separação de poderes com a soberania popular. (JELLINEK, G. Teoría general del Estado. Prólogo y traducción de Fenando de los Ríos. Ciudad de México: Fondo de Cultura Economica, 2000. p. 452-453.

52 CAROLAN, E. The new separation of powers. A theory for the modern State. Oxford: Oxford University Press, 2009. p. 23.

53 ACKERMAN, B. The new separation of powers. Harvard Law Review, Cambridge, vol. 113, n. 3, p. 633-729. jan. 2000. 
O sistema constitucional brasileiro, incorporando a máxima em seu art. $2^{\circ} \mathrm{CF}$, e conferindo-Ihe a especial proteção decorrente do signo de cláusula pétrea no art. 60 , $4^{\circ}$, II CF, aposta no concurso do balanceamento entre poderes para o estabelecimento e mantença do senso de comunidade, e da constituição em si como força unificadora dessa mesma coletividade. Alinha-se então com uma concepção instrumental da separação de poderes, como a sugerida pelo autor americano. Adota-se na presente análise, como critério analítico para a aferição da violação ao modelo de checks and balances, o imputado contraste entre o Novo Regime Fiscal e os valores constitucionais instrumentalizados pelo referido princípio.

\subsubsection{Novo Regime Fiscal e harmonia com o princípio democrático}

No que toca à reverência ao princípio democrático, uma Emenda Constitucional que tem por eixo principal reconciliar a prática da atividade financeira estatal com as limitações que materialmente existem e se tem por apuradas tem em seu favor o primeiro argumento mais fácil, da representação. A intervenção, cunhada pelo mecanismo democrático próprio, observado o devido processo legislativo, e aplicável indistintamente a todos os poderes, revestir-se-ia da legitimidade representativa.

Um segundo ponto - mais sutil - se pode apresentar ainda, em aval ao ideário democrático, decorrente do sistema proposto pela Emenda 95. O thelos da intervenção reformadora reside em reconciliar, repita-se, uma realidade econômica, com as projeções que se apresentam nos instrumentos de planejamento financeiro da atividade pública. A tradução dessa realidade nos orçamentos públicos, já destacava Moreira Neto ${ }^{54}$, envolve investir na democracia substantiva da ação administrativa pública, eis que neles se conterá a "definição monetária da tarefa que a sociedade incumbe ao Estado". Afastar a visibilidade dos programas de ação estatal, traduzidos em instrumentos legislativos dissociados da realidade econômica subjacente contribuiria, portanto, para obscurecer o verdadeiro planejamento de ação das estruturas estatais, resultado incompatível, decerto, com o ideário democrático.

Evocar a separação de poderes para ter-se mantida a prática institucional hoje vigente - ao menos em relação ao Judiciário, como se requer na ADI 5633 - importaria em reforçar uma lógica de dissociação entre a autorização formal das despesas havida em instrumentos orçamentários "otimistas", conduzindo a um artificialismo naive ou intencional dos programas de ação do Estado. Já lecionava Bobbio55 que "democracia é o poder em público", pelo que não favorece à democracia a separação de poderes que se opõe como justificativa para reduzir as luzes sobre a ação financeira.

54 MOREIRA NETO, Diogo de Figueiredo. Democracia e contrapoderes. Revista de Direito Administrativo, Rio de Janeiro, n. 258, p. 47-80, set./dez. 2011. p. 49.

55 BOBBIO, N. Teoria geral da política: A filosofia política e as lições dos clássicos. Tradução Daniela Beccaccia Versiani. 9. ed. reimp. São Paulo: Elsevier Editora, 2000. p. 386. 
O choque produzido pelo Novo Regime Fiscal em verdade reside na sua pretensão de mudança de uma cultura orçamentária avessa a "pronunciar o discurso sobre as políticas públicas e os direitos sociais sob a perspectiva de alocação de verbas orçamentárias".56 No que toca, todavia ao princípio de legitimação sob análise, o apontamento dos instrumentos orçamentários construídos sob a luz do princípio do equilíbrio se constitui igualmente valor constitucional, pelo que, incabível a imputação apriorística do vício de raiz.

\subsubsection{Novo Regime Fiscal, equilíbrio e harmonia entre poderes e especialização funcional}

Observada ainda a abordagem proposta por Ackerman no que toca à instrumentalidade da cláusula constitucional da separação de poderes, tem-se como segundo objetivo possível, a garantia de um nível de especialização e profissionalização em cada qual dos segmentos de atividade estatal que permita o máximo desenvolvimento do projeto de convívio expresso pelo respectivo texto constitucional. Ainda aqui a lógica é de prevenção contra a subordinação, mas de cariz indireto - aquela intervenção alheia ao próprio braço especializado de poder que mina sua independência, logo, sua aptidão para o desenvolvimento da tarefa que lhe foi confiada pela estrutura institucional construída pela Carta de Base.

A questão que se põe é - navega a estrutura central do Novo Regime Fiscal, criando o teto de gastos, no sentido contrário à especialização funcional, protegida pela separação de poderes, em especial, daquele que já provocou o controle abstrato, a saber, o Judiciário?

No que toca especialmente à função jurisdicional, essa lógica se tem por materializada nas garantias de imparcialidade e independência; atributos assegurados seja pela inspiração subjetiva da própria instituição57, seja pelos meios materiais que a preservam de retaliações advindas de qualquer segmento contrariado por eventual decisão judicial.

Neste quadro geral, a interferência que se pode atribuir ao Novo Regime Fiscal diria em tese com as garantias materiais de imparcialidade e independência, eis que impactaria nas despesas autorizadas realizar pelos braços especializados de poder, limitadas na sua expansão ao já realizado, com as atualizações preconizadas pelo próprio regime constitucional. Observe-se que mesmo nesse campo, o impacto a rigor é parcial, eis que o direcionamento interno dos meios disponíveis segue sujeito à sistemática constitucional original, a saber, com a iniciativa reconhecida a cada qual das

56 TORRES, R. L. Tratado de Direito Constitucional, Financeiro e Tributário. Volume V - O orçamento na Constituição. 3. ed. Rio de Janeiro: Renovar, 2008. p. 34.

57 Não há dúvida que também a percepção subjetiva dos integrantes da instituição acerca de seu próprio regime de garantias contribui para o incremento da imparcialidade e independência, com exemplos na história de Cortes com inclinações em ambas as direções. 
estruturas institucionais revestidas de autonomia financeira, observados os parâmetros fixados em LDO. Tenha-se ainda em conta o art. 107, § $9^{\circ}$ do ADCT, que autorizando a compensação entre os limites individualizados dos órgãos elencados em cada inciso do caput, reforça a lógica da independência de cada poder de promover ao direcionamento interno dos meios disponíveis segundo suas próprias prioridades.

A partir dessa constatação - de que o impacto da instituição do Novo Regime Fiscal apresenta-se como contingente e parcial - tem-se já a possibilidade de aplicação da matriz de raciocínio anteriormente desenvolvida pelo STF na ADI 3367 acima referida, em que se conclui pela não violação à independência jurisdicional. É o Ministro Cezar Peluso, então Relator, a afirmação:

A independência suporta, na sua feição constitucional, teores diversos de autonomia administrativa, financeira e disciplinar. Na verdade, ela só pode considerada invulnerável, como predicado essencial do sistema de separação, quando concreta redução de seu âmbito primitivo importe, em dano do equilíbrio e estabilidade entre os poderes [...]. Fora dessas hipóteses, nada obsta que o constituinte reformador lhe redesenhe a configuração histórica, mediante reorganização orgânica e redistribuição de competência no âmbito da estrutura interna do Judiciário.

N'outra passagem ainda deste mesmo acórdão, evoca o Ministro Cezar Peluso o argumento de que se tem preservado o autogoverno do Judiciário, restando intocadas as competências expressas no art. 96 CF. Mais ainda, a criação da estrutura destinada ao controle da atuação administrativa e financeira contribui para o aprimoramento do autogoverno do Judiciário. De todas essas considerações extrai-se que a caracterização da violação à independência do Judiciário - e portanto, o deslustre ao princípio de separação de poderes - reclama: 1) concreta redução do âmbito primitivo de deliberação do poder supostamente alcançado na sua independência; e 2) a adequada gestão administrativa e financeira da estrutura institucional destinatária destas prerrogativas se constitui valor constitucionalmente relevante.

A partir destas premissas, resta saber se a vedação à expansão de despesa para além do critério de atualização preconizado pelo art. 107, § 10, II ADCT importa em si a uma ameaça à independência e imparcialidade como compreendida pela Corte - e a resposta parece ser que não há como se afirmar, ao menos aprioristicamente, essa pretensa relação de causa e efeito entre as duas variáveis que permita a imputação de inconstitucionalidade ao Novo Regime Fiscal.

O argumento manejado pelos contrários à disciplina sob exame é de que a vedação à expansão de gastos para além da variação do IPCA contamine em si a independência - donde essa teria por relevante manifestação, não o livre funcionamento ordinário da estrutura institucional, mas a sua tendência à ampliação e aumento de 
gastos além dos parâmetros já contemplados no art. 107, § 1, II ADCT. A alegação parece insustentável, quando menos como conclusão passível de assentamento apriorístico, portanto suficiente a autorizar $a b$ initio a pronúncia da inconstitucionalidade do Novo Regime Fiscal. Liberdade decisória se tem por assegurada pela existência em si de meios suficientes ao desenvolvimento adequado das atividades - e não necessariamente pela expansão contínua e ilimitada dos gastos.

Ainda que se tenha em conta a curva ainda crescente da judicialização da vida na sociedade brasileira - o que permite inferir um aumento na carga de feitos a serem solvidos pelo Judiciário - disso não decorre uma vez mais, na vigência do teto de gastos, a perda da independência ou imparcialidade. A se manterem constantes as duas variáveis (limitação de gastos e aumento das demandas), ter-se-á um deslocamento do esforço de aprimoramento da função não mais para a contínua e crescente expansão dos gastos, mas para a composição jurisdicional que tenda a gerar efeitos mais amplos na coletividade.58 Tal encaminhamento, é de se dizer, revela-se compatível com as premissas de Planejamento e Gestão Estratégica do Poder Judiciário fixadas pela Resolução CNT no 70, de 18 de março de 2009, que indica como objetivo estratégico no 2, no campo da eficiência operacional, "buscar excelência na gestão dos custos operacionais". Esse indicador estratégico geral foi por sua vez reproduzido mais recentemente na Resolução n 195, de 3 de junho de 2014, que “Dispõe sobre a distribuição de orçamento nos órgãos do Poder Judiciário de primeiro e segundo graus e dá outras providências", onde se dá destaque à relevância da "execução orçamentária equilibrada no âmbito do Poder Judiciário".

Não reside na ameaça à especialização funcional, o argumento para o reconhecimento de vício de raiz à Emeda 95. Resta finalmente a análise da sua interseção com a proteção a direitos fundamentais.

\subsubsection{Novo Regime Fiscal, equilíbrio e harmonia entre poderes proteção a direitos funda- mentais}

A derradeira cogitação a se empreender diz respeito à afirmação de que o Novo Regime Fiscal possa determinar violação ao princípio de separação de poderes ante um potencial à inibição da função institucional de controle da observância dos deveres de agir decorrentes da dimensão objetiva dos direitos fundamentais.

Constitui premissa da análise que permeia todo este artigo, aquela de que a limitação de recursos financeiros é real - e por isso se está aplicando de maneira uniforme a todos os braços especializados de poder. Se isso é assim, a exceção à regra do teto

58 Observe-se que essa estratégia já se tinha posto como prioridade para o Judiciário desde a Emenda 45, e ainda não logrou gerar o efeito de diminuição da massa de demandas que se desejava, como se verifica do relatório Supremo em Números, que dava conta de ter-se alcançado em 2015, a marca de 100 milhões de feito em andamento. 
de gastos reconhecida em favor de uma ou outra estrutura institucional se resolverá, necessariamente, pela compensação dos gastos adicionais de " $\mathrm{A}$ " no total de dispêndio de "B". Esse é o consectário lógico da premissa inicial.

A afirmação de que a instituição do teto de gastos ao Judiciário seja inconstitucional porque mina a potencialidade de, do alto da independência assegurada pela separação de poderes, tutelar-se a direitos fundamentais, levaria à consequência de nulificar-se o limite de dispêndios em relação a qualquer das estruturas de poder.59 Com isso, eventuais ajustes reclamados pelo ideário de equilíbrio fiscal haveriam de se verificar na execução orçamentária, sem prejuízo em princípio, das autorizações de despesas que se tenha assegurado ás instituições dotadas de autonomia financeira. Inverter-se-ia com isso a lógica proposta para Novo Regime Fiscal, para exercer não um controle preventivo ao aumento do déficit, mas para uma ação corretiva, no plano da execução orçamentária, dos efeitos já revelados desse mesmo déficit.

Duas fraturas lógicas se têm nessa argumentação.

Primeiro, assumir como premissa que a construção do orçamento possa se dar descompromissada com o equilíbrio fiscal, porque imune a qualquer limitação em relação aos demais poderes sob pena de violação a cláusula pétrea, entra em rota frontal de colisão com o princípio de equilíbrio orçamentário - que como já se viu, guarda igualmente relações simbióticas com o princípio democrático, à medida em que o orçamento equilibrado é a garantia de transparência e legitimação em relação aos programas de ação do Estado lato sensu.

Segundo problema lógico insuperável no argumento de que limites de gastos se revelem incompatíveis com o valor constitucional de proteção aos direitos fundamentais, está em que, considerada a inequívoca finitude dos recursos financeiros, seu direcionamento prioritário aos órgãos de controle implica em sua subtração das ações públicas de execução dos programas sociais. Uma vez mais, inverte-se a lógica do sistema, afirmando que para proteger direitos fundamentais, seja imperativo assegurar uma capacidade de gastos em favor das estruturas institucionais de controle à custa do financiamento dos direitos fundamentais empreendido diretamente pelo Poder Executivo.

Uma vez mais, é de se destacar que a proteção a direitos fundamentais não se materializa exclusivamente, e menos ainda precipuamente, pela ampliação numérica das demandas individuais, numa rota que estimula a litigiosidade e ataca o fenômeno pela sua manifestação final - e não na sua causa. A preconizada contenção de gastos pode resultar em verdade, na descoberta de uma lógica diferenciada, que privilegie não o conflito individual, mas a jurisdição supervisora, que não se substitui às estruturas formais de poder existentes, mas induz o seu funcionamento regular.

59 O objeto da ADI 5633 em verdade compreende a Emenda 95 como um todo. 
A afirmação de que resida no campo judicial a última trincheira de proteção aos direitos fundamentais se revela quando menos, ingênua, já que existe um mundo de distância entre o dispositivo de sentença, e a tradução daquele proclamado dever de agir no mundo da vida, na realidade da Administração Pública. Esse mesmo discurso, quando utilizado como argumento de proteção contra o limite de dispêndio expressa uma lógica equivocada, em que a atividade-meio passa a se revestir de mais importância do que a atividade-fim. Este não é, concessa máxima vênia, o projeto constitucional.

Não é ocioso trazer à consideração, especialmente quando se cogita da interface entre Novo Regime Fiscal e proteção a direitos fundamentais, que o problema do equilíbrio fiscal não se põe de maneira isolada em relação ao Executivo. Também nesse aspecto, o ideário da unidade do poder se põe, e com isso, a circunstância fática da limitação de recursos se põe igualmente a todos, e reclama para o seu enfrentamento, o desenvolvimento de relações de colaboração - e não de antagonismo.60 Nesse sentido que se diz que a transferência dos efeitos do imperativo do reequilíbrio fiscal ao Poder Executivo não presta a devida reverência, nem aos deveres de proteção aos direitos fundamentais, e menos ainda às relações de colaboração que o ideário de checks and balances em verdade postula.

\section{CONCLUSÃO}

Finalizo este texto, retomando a afirmação anterior de que não se está aqui a defender política ou ideologicamente a proposta materializada no Novo Regime Fiscal. Posta, todavia, a questão da sua constitucionalidade, isso é de ser examinado de forma desapaixonada, observadas as premissas que a doutrina e a jurisprudência já traçaram.

Indiscutível a importância, numa democracia jovem como ainda o é a brasileira, de preservar-se as estruturas institucionais de controle. Não menos importante é a consolidação de uma cultura de controle que se revele não só harmônica com seus fins, mas coerente com a própria supervisão que este mesmo sistema desenvolve. Dromi já assinalava que o controle é uma tarefa de cotejo da legitimidade dos meios com os fins alcançados61 - e se isso se exige do controlado, da mesma maneira é de se exigir do controlador. Dessa máxima resultará que não é a simples qualificação da atividade como de controle que autorizará seu apartamento de outros critérios e valores constitucionais igualmente relevantes como o do equilíbrio orçamentário, da transparência no que toca à real programação de ação governamental, e da accountability.

60 É de Queiroz a afirmação de que a dissociação entre atividades executivas e aquelas de controle apontam antes para uma relação de compartilhamento de poder, com interdependência e colaboração de poderes que se reforçam mutuamente. (QUEIROZ, C. Direito Constitucional. As instituições do Estado Democrático e Constitucional. Coimbra-São Paulo: Coimbra Editora e Editora Revista dos Tribunais, 2009. p. 405).

61 DROMI, R. Modernización del control público. Madrid: Hispania Libros, 2005. p. 36. 
A afirmação apriorística da inconstitucionalidade do Novo Regime Fiscal a partir de uma violação presumida e prospectiva da cláusula de separação de poderes traduz uma pretensão de conferir-se a esse mesmo preceito, um elastério que a sua justificação finalística parece não comportar. Navega-se aqui na utilização retórica de uma cláusula indeterminada, como verdadeira justificativa ex post ante de uma rejeição à proposta que tem outras origens - e que, portanto, hão de ser exploradas em outras arenas, do debate político e ideológico, mas não do controle jurisdicional.

Incorporado o caráter necessariamente dinâmico de que se revestem os textos constitucionais, indispensável reconhecer que a lógica do sistema é da presunção de constitucionalidade também das emendas - o que não recomenda a proclamação do vício de raiz da deliberação parlamentar a partir de ecos das Cassandras de plantão.

Não se está com isso a sustentar não se possa com o tempo, e a partir de uma experiência de aplicação que revele efeitos que permitam uma análise real, retomar o tema da constitucionalidade do Novo Regime Fiscal. Vale aqui, a lição de Couture - o tempo se vinga das coisas que são feitas sem o seu concurso.

\section{REFERÊNCIAS}

ACKERMAN, B. The new separation of powers. Harvard Law Review, Cambridge, vol. 113, n. 3, p. 633-729. jan. 2000.

BOBBIO, N. Teoria geral da política: A filosofia política e as lições dos clássicos. Tradução Daniela Beccaccia Versiani. 9. ed. reimp. São Paulo: Elsevier Editora, 2000.

CAROLAN, E. The new separation of powers. A theory for the modern State. Oxford: Oxford University Press, 2009.

COUTO, Cláudio G.; ABRUCIO, Fernando. O segundo governo FHC: coalizões, agendas e instituições. Tempo social. São Paulo, v. 15, n. 2, 2003. Disponível em: < http://www.scielo.br/scielo. php?script=sci_arttext\&pid=S010320702003000200011\&lissoen\&nrm=iso>. Acesso em: 27 fev. 2009.

DROMI, R. Modernización del control público. Madrid: Hispania Libros, 2005.

FURTADO, J. R. Caldas. Elementos de Direito Financeiro. 2. ed. rev., ampl. e atual. Belo Horizonte: Editora Fórum, 2010.

GRAZIANE, E. P. Sociedade que não planeja aceita a má qualidade do gasto público. Consultor Jurídico, São Paulo, dez. 2016. Disponível em: < http://www.conjur.com.br/2016-dez-06/contas-vista-sociedade-nao-planeja-aceita-ma-qualidade-gasto-publico>. Acesso em: 03 jan. 2017.

JELLINEK, G. Teoría general del Estado. Prólogo y traducción de Fenando de los Ríos. Ciudad de México: Fondo de Cultura Economica, 2000.

MIRANDA, Jorge. Teoria do Estado e da Constituição. Rio de Janeiro: Forense, 2002. 
MOREIRA NETO, D.F. Considerações sobre a Lei de Responsabilidade Fiscal: Finanças públicas democráticas - Com a colaboração de Silvio Freitas de Moraes. Rio de Janeiro: Renovar, 2001.

MOREIRA NETO, Diogo de Figueiredo. Democracia e contrapoderes. Revista de Direito Administrativo, Rio de Janeiro, n. 258, p. 47-80, set./dez. 2011.

OLIVEIRA, R. F. de. Curso de Direito Financeiro. 7. ed. rev., atual. e ampl. São Paulo: Thomson Reuteures-Revista dos Tribunais, 2015.

PIÇARRA, N. A separação dos poderes como doutrina e princípio constitucional: Um contributo para o estudo das suas origens e evolução. Coimbra: Coimbra Editora Limitada, 1989.

QUEIROZ, C. Direito Constitucional. As instituições do Estado Democrático e Constitucional. Coimbra-São Paulo: Coimbra Editora e Editora Revista dos Tribunais, 2009.

SARLET, I. W.; MARINONI, L. G.; MITIDIERO, D. Curso de Direito Constitucional. São Paulo: Editora Revista dos Tribunais, 2012.

SCAFF, F. F. Retrospectiva 2016: "Farinha pouca, meu pirão primeiro" e a overdose de Direito Financeiro. Consultor Jurídico, São Paulo, dez. 2016. Disponível em: < http://www.conjur.com. br/2016-dez-27/retrospectiva-2016-farinha-meu-pirao-primeiro-overdose-direito-financeiro >. Acesso em: 28 dez. 2016.

TORRES, R. L. Tratado de Direito Constitucional, Financeiro e Tributário. Volume V - O orçamento na Constituição. 3. ed. Rio de Janeiro: Renovar, 2008.

VALLE, V. R. L. A Constituição como sistema: retomando uma premissa à efetividade. In: FERRARI, S.; MENDONÇA, J. S. (Org.). Direito em Público: Homenagem ao Professor Paulo Braga Galvão. Rio de Janeiro: Lumen Juris, 2016.

VALLE, V. R. L. Transição política e construtivismo constitucional: uma análise empírica das emendas constitucionais brasileiras. In: CAMARGO, M. M. L.; LOIS, C. C.;MARQUES, G. L. (Org.). Democracia e jurisdição: novas configurações brasileiras. Rio de Janeiro: Imo's Graf. e Ed., 2013. 